\title{
ON THE INTERPLAY BETWEEN HYDRODYNAMICS, BOTTOM MORPHOLOGY, SEDIMENTARY PROCESSES AND BENTHIC FORAMINIFERA ASSEMBLAGES IN THE SÃO PAULO BIGHT (BRAZIL, SW ATLANTIC)
}

\section{Cintia Yamashita ${ }^{1 *}$, Renata Hanae Nagai ${ }^{2}$; MARIa Virgínia Alves Martins ${ }^{3,4}$, Thaisa MarQues VicENTE ${ }^{1}$, Silvia Helena de Mello e Sousa ${ }^{1}$, Fabrizio Frontalini ${ }^{5}$, ANDré Palóczy ${ }^{1}$, Michel MichaelovitCh De MaHiQues ${ }^{1}$, Sueli SUSANA DE GODOI ${ }^{1}$, ISABEL MONTOYA-MONTES ${ }^{1}$ AND RUBENS CESAR LOPES FiguEIRA ${ }^{1}$}

1 Departamento de Oceanografia Química, Física e Geológica, Instituto Oceanográfico, Universidade de São Paulo, Praça do Oceanográfico, 191. Cidade Universitária. 05508-120. São Paulo, Brazil. cintia.yamashita@usp.br, thaisamv@gmail.com, smsousa@usp.br, paloczy@gmail.com, mahiques@gmail.com,ssdgodoi@usp.br, isabel.montoya@usp.br, rfigueira@usp.br

2 Centro de Estudos do Mar, Universidade Federal do Paraná, AV. Beira Mar, s/n. Pontal do Paraná, Paraná, Brazil. renatanagai@usp.br

3 Universidade do Estado do Rio de Janeiro, Faculdade de Geologia, Departamento de Estratigrafia e Paleontologia. Av. São Francisco Xavier, 524, sala 2020A, Maracanã. 20550-013 Rio de Janeiro, RJ, Brazil.virginia.martins@ua.pt

4 Universidade de Aveiro, GeoBioTec, Departamento de Geociências, Campus de Santiago, 3810-193 Aveiro, Portugal.

5 Dipartimento di Scienze Pure e Applicate (DiSPeA) Università degli Studi di Urbino "Carlo Bo". Università degli Studi di Urbino Carlo Bo. Piazza della Repubblica, 13 - 61029 Urbino, Italy. fabrizio.frontalini@uniurb.it

*Corresponding author, cintia.yamashita@usp.br

Received on 01 September 2016

Received in revised form on 09 October 2016

Accepted on 10 October 2016

Editor:

Maria Antonioeta da Conceição Rodrigues, Universidade do Estado do Rio de Janeiro, Brazil
Citation:

Yamashita, C., Nagai, R.N., Martins, M.V.A., Vicente, T.M., Sousa, S.H.M., Frontalini, F., Palóczy, A., Mahiques, M.M., Godoi, S.S., Montoya-Montes, I., Figueira, R.C.L., 2016. On the interplay between hydrodynamics, bottom morphology, sedimentary processes and benthic foraminifera assemblages in the São Paulo Bight (Brazil, SW Atlantic). Journal of Sedimentary Environments, 1(3): 326-347.

\section{Abstract}

Surface sediment samples recovered in the São Paulo Bight (SW Atlantic) were collected between 45 to $1132 \mathrm{~m}$ water depths to characterize sedimentary processes based on a multiproxy approach. This study analysis benthic foraminifera and abiotic data, including granulometry, TOC and $\mathrm{C} / \mathrm{N}$ values. Spatial and yearly distributions of ocean chlorophyll-a concentrations [Chl-a] evaluated from available SeaWiFS Chlorophyll Ocean Colour Images also were analyzed. On the basis of the non-metric Multidimensional Scaling analysis two regions with different characteristics were identified (1) São Sebastião Island and (2) Grande Island. The $\mathrm{C} / \mathrm{N}$ results indicate that in most of the studied stations the organic matter supplied to the sea bottom is provided essentially by oceanic productivity. Concentrations of chlorophyll- $a$ and TOC are higher in Grande Island region than in the São Sebastião Island sector. In the first region the benthic foraminifera assemblages are larger but less diversified than in São Sebastião Island sector. The foraminifera assemblages of Grande Island region are dominated by Globocassidulina subglobosa and composed mostly by opportunist species related to episodic availability of food inputs related to the Cabo Frio upwelling system. The influence of this system seems to decrease in São Sebastião Island sector. In the deeper slope stations of the São Sebastião Island region, the presence of an arborescent community (Rhadammina spp. and Rhizammina spp.) and Nodulina dentaliniformis suggests that the sedimentary regime is relatively more stable and contain a higher amount of refractory organic than in Grande Island region for the similar range of depths.

Keywords: Benthic foraminifera. Chlorophyll- $a$ concentrations. TOC. C/N. Upwelling system. Continental margin 


\section{Introduction}

The composition of benthic foraminiferal assemblages is determined by the relationships among oceanographic, trophic and sedimentological conditions (Schmiedl et al., 1997; Jorissen et al., 2007; Burone et al., 2011). The quality, quantity and seasonality of organic matter supplied to the seafloor are considered the main factors influencing benthic foraminiferal distributions (e.g. Schmiedl and Mackensen, 1997; Den Dulk et al., 1998; Jorissen et al., 2007).

In deep-sea ecosystems, vertical and horizontal organic matter fluxes, oxygen availability and redox conditions in bottom and interstitial waters are the most important factors controlling benthic foraminiferal abundance, community structure and distribution (e.g. Schmiedl et al., 2000; Morigi et al., 2001).

The non-linear relationship between primary productivity and organic matter in bottom sediments may be commonly associated with local environmental variability such as surface currents, meanders, eddies, lateral flux of any kind, bottom morphology, sedimentation rate and degradation of particulate organic matter in the water column (Klaas and Archer, 2002; Boyd and Trull, 2007).

Several authors, (e.g. Fontanier et al., 2008; Koho et al., 2008; Hess and Jorissen, 2009) have considered bottom morphology one of the main factors influencing the distribution of benthic foraminifera in deep sea systems. Therefore, it is reasonable to expect differences in benthic foraminiferal assemblages along the open shelf and open slope environment.

Recent benthic foraminiferal fauna from the southeastern Brazilian continental margin has been poorly studied. Indeed, a limited number of studies have focused on the southeastern Brazilian continental margin area (e.g. Sousa et al., 2006; Eichler et al., 2008; Burone et al., 2011).

\subsection{Objective of the work}

To the best of our knowledge, no study has analyzed other important factors such as the interplay between foraminifera and the sedimentary dynamics itself in the southeastern Brazilian continental margin.

In light of it, this work aims to unravel the distribution of the recent benthic foraminifera and their relationships with the hydrodynamic conditions and bottom floor morphology in the southeastern Brazilian continental shelf and slope $\left(23^{\circ} 20^{\prime} \mathrm{S}-25^{\circ} 02^{\prime} \mathrm{S}\right.$ and $\left.43^{\circ} 50^{\prime} \mathrm{W}-45^{\circ} 10^{\prime} \mathrm{W}\right)$ between $40 \mathrm{~m}$ and $1000 \mathrm{~m}$ depth.

\section{Study area}

The study area is located on the continental shelf and slope off the southeastern Brazilian continental margin, in São Paulo Bight (Zembruscki, 1979), between São Sebastião Island and Grande Island (Figure 1A-B).

The seafloor morphology of São Paulo Bight presents several channels and canyons in the slope (Furtado et al., 1996) and exposes paleo-rivers in the shelf (Conti and Furtado, 2006; Conti, 2009). The shelf break is located at approximately $140 \mathrm{~m}$ depth. In the eastern sector off São Sebastião Island (approximately at $24^{\circ} \mathrm{S}, 45^{\circ} 30^{\prime} \mathrm{W}$ ), the upper slope changes into a fan-shaped feature at the end of the Búzios Channel (Mahiques et al., 2007).

The mean circulation on the continental shelf and the upper slope of the southeastern Brazilian margin is linked to the western boundary current system of the South Atlantic Subtropical gyre that includes the Brazil Current System and the Intermediate Western Boundary Current (IWBC).

The Brazil Current System consists of the Brazil Current (BC) and their meanders and eddies (Figure 1B). The BC activity generates thermal fronts that are known to have important temporal and spatial variability in the study area (Silveira, 2007). According to Campos et al. (1995), the BC develops a convoluted pattern of meanders on the Cabo Frio surroundings due to the change in the Brazilian coastline orientation that dynamically favors the formation of cyclonic and anti-cyclonic meanders. The BC transports Tropical Water (TW, T $>20.0^{\circ} \mathrm{C}, \mathrm{S}>36.40$ ) at upper levels and South Atlantic Central Water (SACW, T $<20.0{ }^{\circ} \mathrm{C}, \mathrm{S}<$ 36.40) at pycnocline levels (Miranda, 1985; Castro and Miranda, 1998) reaching current speeds between $0.4 \mathrm{~m} . \mathrm{s}^{-1}$ and $0.7 \mathrm{~m} . \mathrm{s}^{-1}$ (Silveira et al., 2008).

Below the SACW, the Antarctic Intermediate Water (AAIW) flows northward of $25^{\circ} \mathrm{S}$, carried by the IWBC (Silveira et al., 2000), which flows north-northeastward with a maximum current speed of 0.3 m.s ${ }^{-1}$ (Silveira, 2007).

In the Cabo Frio area, the seasonal cycle of the prevailing wind direction over the continental shelf establishes seasonal upwelling due to Ekman dynamics (Castro et al., 1987; Campos et al., 2000). In summer, upwelling is intensified by the dominant NE winds, which favor the transport to offshore of the surface Costal Water (CW) and the consequent penetration of the subsurface SACW in shallower areas (Castro, 1996). The inner shelf is characterized by the interaction of TW and SACW with the alongshore and offshore displacement of the $\mathrm{CW}$ $\left(\mathrm{T}=24.0^{\circ} \mathrm{C}, \mathrm{S}=34.9\right.$ ) (Castro et al., 1987; Signorini et al., 1989). 


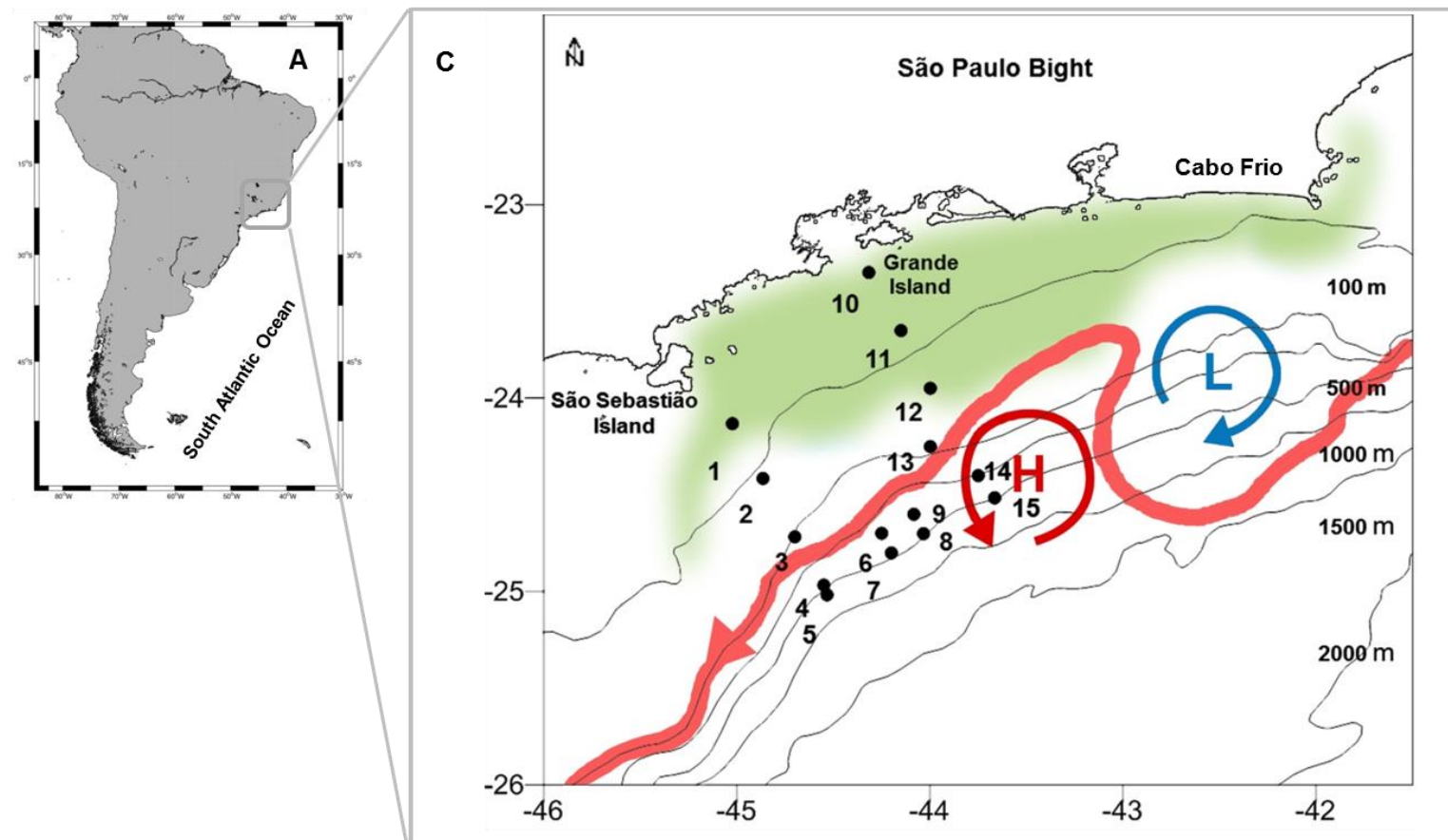

B

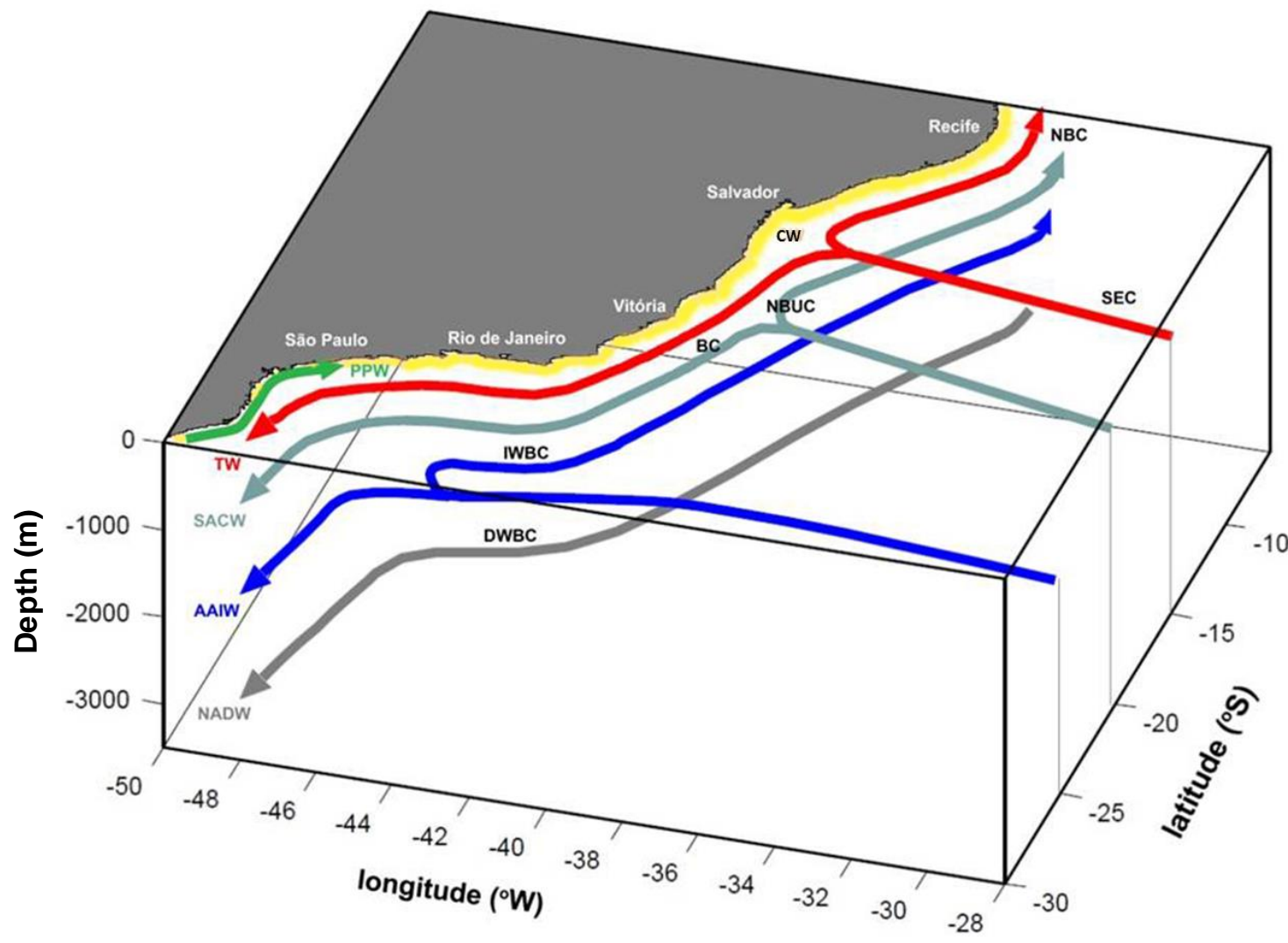


Fig. 1: Location of the study area and oceanographic features. A) South America; B) Schematic representation of the vertical structure of the western boundary current system and associated water masses off the eastern and southeastern Brazilian coast: Coastal Water (CW_yellow); Brazil Current (BC), Tropical Water (TW—red) and South Atlantic Central Water (SACW-gray); Intermediate Western Boundary Current (IWBC)—Antarctic Intermediate Water (AAIW—blue); North Atlantic Deep Water (NADW— dark gray); Deep Western Boundary Current (DWBC); South Equatorial Current (SEC); North Brazil Current (NBC); North Brazil Undercurrent (NBUC); Plata Plume Water (PPW-green) (Based on Stramma and England (1999), Piola et al., (2008) and Soutelino (2013). C) Map with the location of the sampling stations, semi-permanent oceanographic features of the Brazil Current (red); Cabo Frio cyclonic eddy (blue), anti-cyclonic eddy (red), Cabo Frio upwelling (green), and episodic oceanographic features: Cold water advected to the shelf (cyan), eddies (blue and red) and Cabo Frio upwelling Plume (dark green) in the southeastern Brazilian continental margin (based on Velhote (1998), Campos et al. (2000), Cerda and Castro (2013) and Mazzini and Barth, (2013).

Shelf break upwelling associated with propagating cyclonic eddies of the BC in the southeast Brazil Bight has already been observed (Campos et al., 2000). Moreover, shelf break upwelling induced by the growth of quasi-standing cyclonic BC meanders has been shown to have an important effect in SACW pumping from the slope onto the shelf northward of our study region (Palóczy et al., 2013). However upwelling cells and plumes are frequently observed southward of Cabo Frio (Figure 1). The strongest upwelling signal (lowest surface temperature) occurs near Cabo Frio and spreads southward (Cabo Frio plume) (Rodrigues and Lorenzzetti, 2001; Mazzini and Barth, 2013).

Due to the oceanographic and climatic conditions at the southeastern Brazilian margin the phytoplankton biomass and primary production have large spatial and temporal variability (Marone et al., 2010). During winter, coastal primary production may occasionally attain higher values than those during summer due to SACW shelf intrusions (Marone et al., 2010).

Despite the upwelling events, the inner and the outer shelf within the study area are respectively considered oligomesotrophic (Saldanha-Corrêa and Gianesella, 2008) and oligotrophic (Burone et al., 2011).

The export of biological production, phytodetritus deposition, as well as sedimentary processes are controlled by Brazil Current meandering, eddy formation, coastal and shelf break upwelling and Ekman transport (Mahiques et al., 2002, 2004).

Offshore transport of shelf waters driven by eddy-like BC meanders are likely to be the most important mechanisms promoting exchange between the shelf and the deep ocean (Mahiques et al., 2002, 2004). In the São Sebastião Island area, Ekman dynamics drive CW offshore and transports terrigenous suspended material to deeper areas (Mahiques et al., 1999).

Depositional processes northward of São Sebastião Island are influenced by seasonal upwelling (particularly in the Cabo Frio region) and coastal processes (Mahiques et al.,
2004). Both coastal currents and the BC tend to commonly flow southward/southwestward in this sector, making the São Sebastião Island area a convergence zone of sediment transport (Gyllencreutz et al., 2010).

In general, the Holocene seafloor of the São Paulo Bight is covered by siliciclastic very fine sands and silts, with variable amounts of clay and calcium carbonate (Mahiques et al., 2002). Coarser sediments and carbonate gravel of the outer shelf, which represent less than $5 \%$ of the present bottom sediments, are generally related to relict sediments, deposited under lower sea-level conditions (Mahiques et al., 2002).

\section{Material and methods}

In order to characterize the geomorphology of the area where the sediments were collected, a Digital Elevation Model was obtained from the General Bathymetric Chart of the Oceans (GEBCO). The continuous 30-arc-second terrain model, which includes a database of ship-track soundings with interpolation between soundings guided by satellite-derived gravity data, was used.

The chlorophyll- $a$ concentration ([Chl-a]) maps derived from SeaWiFS [Chl-a] ocean colour images were used to evaluate the spatial and yearly distributions of this variable between 1998 and 2003. The zonal-temporal diagrams were established for 5 years using data available before the collection of the samples.

\subsection{Sediment samples and grain size and geochemical data}

Fifteen sediment core samples were collected in 2003 aboard the R.V. "Prof. W. Besnard" (Figure 1C, Table 1). Samples were recovered using a box-core sampler along four transects between $40 \mathrm{~m}$ and $1000 \mathrm{~m}$ depth: T1 off São Sebastião Island, T4 off Grande Island and T2, T3 between the previous ones. The topmost $2 \mathrm{~cm}$ of the sediments were 
recovered from each station and analyzed for grain-size and calcium carbonate, total organic carbon (TOC), nitrogen contents $(\mathrm{N})$ and benthic foraminifera content. Sediment samples used for foraminiferal analysis were preserved on board with an alcohol solution (70\%) with Bengal Rose (1 $\mathrm{g} / \mathrm{L})$.

Sediment grain-size was determined in decarbonated samples using a Malvern Mastersizer 2000 analyzer and classified according to Folk and Ward (1957) grain size parameters. The calcium carbonate content $\left(\mathrm{CaCO}_{3}\right)$ was determined by weight difference before and after acidification of $2 \mathrm{~g}$ of each sample with $1 \mathrm{~N} \mathrm{HCl}$. The TOC and $\mathrm{N}$ contents were evaluated using a LECO CNS2000 Analyser.

\subsection{Foraminiferal Analysis}

The sedimentary fraction $>63 \mu \mathrm{m}$ was used for benthic foraminiferal studies. The abundance and composition of the dead assemblages are analyzed in this work since the living ones were poorly represented during the sampling event. Subsamples of about $10 \mathrm{~cm}^{3}$ of each sample were wet sieved through a $63 \mu \mathrm{m}$ mesh and used to determine foraminiferal density (FD; number of specimens per $10 \mathrm{ml}$ ).

For benthic foraminiferal assemblages composition, approximately 300 specimens (empty and well preserved tests, without signs of transportation) were analyzed in the sediment fraction $>63 \mu \mathrm{m}$. Tubular fragments were considered to be equivalent to one third of a specimen (Harloff and Mackensen, 1997; Heinz and Hemleben, 2003) to avoid overestimation of tubular specimens.

Benthic foraminifera were taxonomically identified using taxonomic references such as those of Ellis and Messina (1940 et seq.), Boltovskoy et al. (1980), van Morkoven et al. (1986), Loeblich \& Tappan (1988), Yassini and Jones (1995), Jones (1994), Murray (2003) and Martins and Gomes (2004). The name of each species was checked and revised in accordance to the on-line database WoRMS (World Register of Marine Species; Hayward et al., 2016). All the specimens were stored in micropaleontological slides. The relative abundances of the recognized species in each sample were calculated. Some species found in the region were imaged with a digital Scanning Electron Microscope (SEM).

\subsection{Statistical analyses}

Ecological parameters were evaluated using the Shannon diversity index ( $\mathrm{H}^{\prime}$, in natural logarithm scale) (Shannon, 1948) and Pielou equitability (J') (Pielou 1975).
Species with relative abundance higher than $3 \%$, in at least one sample, were selected for statistical analysis. Multidimensional Scaling (nMDS) was applied to discriminate the short-distance region (similarity) or to group stations with similar distribution patterns between biotic (FD, J', H', and the most abundant species) and abiotic parameters (TOC, C/N and percentage of sand). Spearman correlation was used in nMDS. All statistical analyses were performed in PAST (Hammer et al., 2001).

The biotic and abiotic distribution maps were prepared using the $\operatorname{Surfer}{ }^{\circledR}$ (version 8). The shoreline was obtained by General Bathymetric Chart of the Oceans (GEBCO), and the datum was World Geodetic System 1984 (WGS-84). The data has a spatial resolution of $0.062^{\circ}$ latitude and longitude.

\section{Results}

\subsection{Digital Elevation Model}

The geomorphology and bathymetry of the study area (Figure 2) suggest the presence of accentuated depth gradient structures across the shelf and slope $(4,5,6,7,8$, and 9 station), and flat open shelf/slope surfaces (10 to 13 stations).

\subsection{Chlorophyll-a concentration}

Figures $3 \mathrm{~A}$ and $3 \mathrm{~B}$ illustrate the annual and spatial distributions of the available satellite derived [Chl-a] in the study region previous to the sediment core sampling for the period between 1998-2003. The highest values of [Chl-a] (over $0.5 \mathrm{mg} \cdot \mathrm{m}^{-3}$ ) occur northward of $23^{\circ} \mathrm{S}$ while lower values (between $0.08 \mathrm{mg} \cdot \mathrm{m}^{-3}$ and $0.5 \mathrm{mg} \cdot \mathrm{m}^{-3}$ ) are observed southward of $23^{\circ} \mathrm{S}$ (Figure $3 \mathrm{~A}, \mathrm{~B}$ ). There is a pulse in [Chla] (from $0.5 \mathrm{mg} \cdot \mathrm{m}^{-3}$ to $10 \mathrm{mg} \cdot \mathrm{m}^{-3}$ ) around $44^{\circ} \mathrm{W}$. In the nearshore areas, between $45^{\circ} \mathrm{W}$ and $46^{\circ} \mathrm{W}$, high [Chl-a] (from $0.5 \mathrm{mg} \cdot \mathrm{m}^{-3}$ to $10 \mathrm{mg} \cdot \mathrm{m}^{-3}$ ) is also observed.

\subsection{Sedimentological and geochemical data}

The sedimentological and geochemical data of studied stations are reported in Table 1. Considering the mean diameter of the sediments (varying between 2-6 $\phi$ ), grain size of the studied samples varies between very fine silt and medium sand. The highest (71\%) and lowest (6.3\%) sand contents are observed at stations 11 and 9, respectively. The finer sediments are mainly found at distal stations (Figure 4). The highest value of TOC is observed at stations 11 (T4, $\left.11.1 \mathrm{mg} \mathrm{g}^{-1}\right)$ and the lowest one at station 1 (T1, $3 \mathrm{mg} \mathrm{g}^{-1}$ ). 


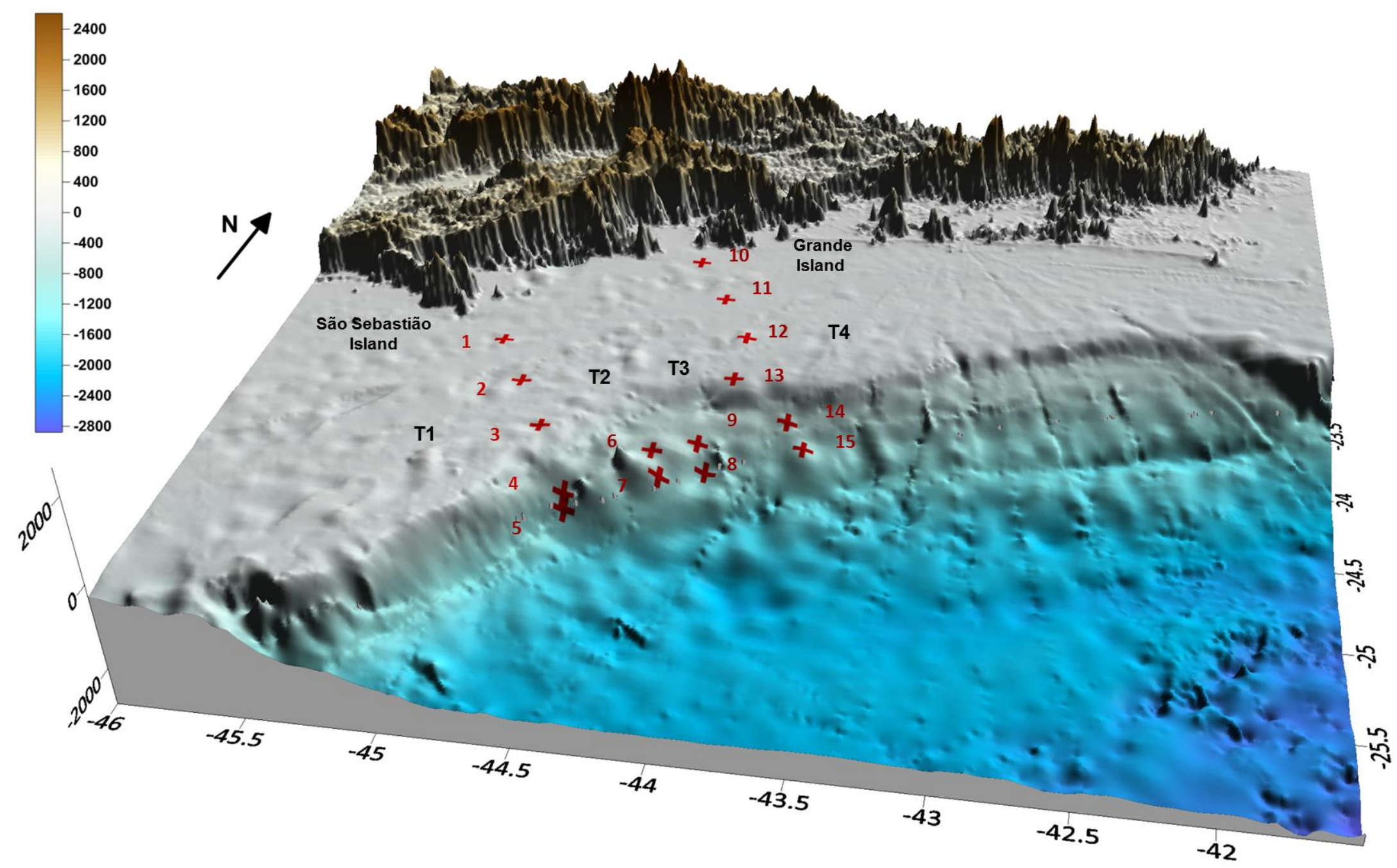

Fig. 2. Digital Elevation Model with the plotted stations. 
Tab. 1. Sampling location, water depth, sedimentological and oceanographic data. Lat.: latitude ( $\left.{ }^{\circ} \mathrm{S}\right)$; Long.: longitude ( $\left.{ }^{\circ} \mathrm{W}\right)$; Depth (m); TOC: total organic carbon $(\mathrm{mg} / \mathrm{g}) ; \mathrm{C} / \mathrm{N}$ : Carbon and Nitrogen ratio; Sand: sand fraction (\%); and MD: mean diameter ( $\left.{ }^{\Phi}\right)$.

\begin{tabular}{lccccccc}
\hline Station & Depth $(\mathbf{m})$ & Lat. $\left({ }^{\circ} \mathbf{S}\right)$ & Long. $\left({ }^{\circ} \mathbf{W}\right)$ & TOC $(\mathbf{m g} / \mathbf{g})$ & $\mathbf{C} / \mathbf{N}$ & Sand (\%) & MD $(\mathbf{\Phi})$ \\
\hline $\mathbf{1}$ & 76 & -24.1 & -45 & 4 & 7.5 & 60 & 3 \\
\hline $\mathbf{2}$ & 121 & -24.4 & -44.9 & 5 & 8.4 & 20 & 5 \\
\hline $\mathbf{4}$ & 156 & -24.7 & -44.7 & 3 & 6 & 20 & 5.9 \\
\hline $\mathbf{5}$ & 765 & -25 & -44.6 & 9.3 & 7.2 & 30 & 4.9 \\
\hline $\mathbf{6}$ & 1132 & -25 & -44.5 & 10 & 9.1 & 19 & 5.4 \\
\hline $\mathbf{7}$ & 621 & -24.7 & -44.3 & 5.7 & 8.8 & 12.3 & 5.8 \\
\hline $\mathbf{8}$ & 964 & -24.8 & -44.2 & 8.5 & 7 & 31 & 5 \\
\hline $\mathbf{9}$ & 983 & -24.7 & -44 & 7.9 & 7.3 & 31 & 5 \\
\hline $\mathbf{1 0}$ & 687 & -24.6 & -44.1 & 5 & 16.6 & 6.3 & 5.6 \\
\hline $\mathbf{1 1}$ & 45 & -23.4 & -44.3 & 11 & 5.5 & 66.3 & 2.9 \\
\hline $\mathbf{1 2}$ & 83 & -23.7 & -44.2 & 11.1 & 8.1 & 71 & 3 \\
\hline $\mathbf{1 3}$ & 126 & -23.9 & -44 & 7 & 10.2 & 23.1 & 4.8 \\
\hline $\mathbf{1 4}$ & 203 & -24.3 & -44 & 5 & 6 & 40.2 & 4.5 \\
\hline $\mathbf{1 5}$ & 652 & -24.4 & -43.8 & 9 & 8 & 11.2 & 5.8 \\
\hline & 1000 & -24.5 & -43.7 & 7.1 & 8.6 & 10 & 5.8 \\
\hline
\end{tabular}

Relatively high TOC contents $(5-10 \mathrm{mg} / \mathrm{g})$ are also found in deeper stations (4, 5, 6, 7, 8, 9, 14 and 15, Figure 4). The $\mathrm{C} / \mathrm{N}$ ratio presents the highest value at station $9(\mathrm{~T} 3,16.6)$ and the lowest (5.5-7.5) at stations 1, 3, 10 and 13 (Figure 4).

\subsection{Benthic foraminiferal data}

The FD varies between 315 and 42066 specimens per 10 $\mathrm{cm}^{3}$ of sediment (Table 2 and Figure 5). A total number of 310 benthic foraminiferal species was identified in the studied samples. The benthic foraminiferal parameters (FD, H', J') are reported in Table 2 and plotted in Figure 5. Stations 12,13, 14 and 15 (T4) presented the highest values of FD (33721 to 42066 ind. $/ 10 \mathrm{~cm}^{3}$ ) than transect T1 (315 to 2806 ind./ $\left.10 \mathrm{~cm}^{3}\right)$. The lowest FD value is observed at station 5 (315 ind. $/ 10 \mathrm{~cm}^{3}$ ).

$\mathrm{H}^{\prime}$ values are relatively high in T2 and T3 (3.05-3.69) and low in T4 (1.23-2.84). The highest FD in T4 is particularly marked at distal sites, although they commonly match with minimal values of $\mathrm{H}^{\prime}$ and J' (Figure 4, Table 2).

The percentage of foraminiferal species in the studied samples (that reach a relative abundance $>3 \%$ in at least one station) are presented in Appendix 1. SEM photos of some species found in the region were included in plate 1.

Species such as Globocassidulina subglobosa (up to $78 \%$ at station 10) and Cassidulina laevigata/ carinata (up to $26 \%$ at station 13) dominate in transect T4. The benthic foraminiferal assemblages of transects T1, T2 and T3 include mostly species such as: Planulina ariminensis (up to $31 \%$ at station 4), Uvigerina peregrina (up to $26 \%$ at station 8), Rhabdammina spp. (up to $7.6 \%$ at stations 7 and 13), Hoeglundina elegans (up to 7\% at station 7), Cibicides wuellerstorfi (up to $5 \%$ at station 5) and Nodulina dentaliniformis (up to $4 \%$ at station 8) (Figure 6). The H' and J'values are higher in these transects than in T4 (Table 2; Figure 5).

\subsection{Statistical Results}

The nMDS analysis based on biotic (FD, J', H', and the most abundant species: Bulimina marginata, $C$. laevigata/ $C$. carinata, C. wuellerstorfi, Epistominella exigua, G. subglobosa, Pullenia quinqueloba, $H$. elegans, $P$. ariminensis, $N$. dentaliniformis, Rhabdammina spp. and U. peregrina) and abiotic parameters (TOC, $\mathrm{C} / \mathrm{N}$ and percentage of sand) allows to recognize two regions of shortest distance correlation (Figure 7A). 
Tab. 1. Foraminiferal density (FD), equitability (J'), and Diversity $\left(\mathrm{H}^{\prime}\right)$.

\begin{tabular}{lccc}
\hline Station & $\begin{array}{c}\text { FD } \\
\text { (ind./10cc) }\end{array}$ & $\mathbf{J}$ & $\mathbf{H}^{\prime}$ \\
\hline $\mathbf{1}$ & 950 & 0.74 & 2.98 \\
\hline $\mathbf{2}$ & 963 & 0.78 & 3.33 \\
\hline $\mathbf{3}$ & 2806 & 0.78 & 3.49 \\
\hline $\mathbf{4}$ & 374 & 0.77 & 2.88 \\
\hline $\mathbf{5}$ & 315 & 0.81 & 3.13 \\
\hline $\mathbf{6}$ & 972 & 0.83 & 3.69 \\
\hline $\mathbf{7}$ & $\mathbf{7 9 1}$ & 0.79 & 3.29 \\
\hline $\mathbf{8}$ & 564 & 0.78 & 3.06 \\
\hline $\mathbf{9}$ & 2408 & 0.74 & 3.05 \\
\hline $\mathbf{1 0}$ & 838 & 0.34 & 1.23 \\
\hline $\mathbf{1 1}$ & 6284 & 0.5 & 1.81 \\
\hline $\mathbf{1 2}$ & 42066 & 0.53 & 2,00 \\
\hline $\mathbf{1 3}$ & 34596 & 0.6 & 2.84 \\
\hline $\mathbf{1 4}$ & 39613 & 0.53 & 2.36 \\
\hline $\mathbf{1 5}$ & 33721 & 0.54 & 2.16 \\
\hline & & & \\
\hline & & & \\
\hline
\end{tabular}

These two regions are defined as São Sebastião Island area, which includes stations from T1, T2 and T3, and Grande Island area that groups all the T4 stations (Figure $7 \mathrm{~B})$.

\section{Discussion}

The BC dynamics makes the outer shelf/upper slope a high energy area (mean current speed $\sim 0.40-0.70 \mathrm{~m} \mathrm{~s}^{-1}$ ) (Silveira et al., 2000, 2008). The episodic perturbation of the BC modulates the occurrence of eddies (Figure 1). Moreover, the wind driven offshore movement of the CW can potentially disturb the seafloor (Mahiques et al., 1999). Currents activity can cause seafloor disturbances and rework sediments through the "tea-cup effect" linked to the decrease of the eddy velocity along the water column (Viana et al., 1998).

In the São Paulo Bight modern sedimentation rates vary from 0.5 to $66 \mathrm{~cm} \mathrm{kyr}^{-1}$ and low sedimentation rate values are found in the outer shelf, associated with the BC main flow, which acts as a "floor-polisher" on the seafloor (Mahiques et al., 2002).
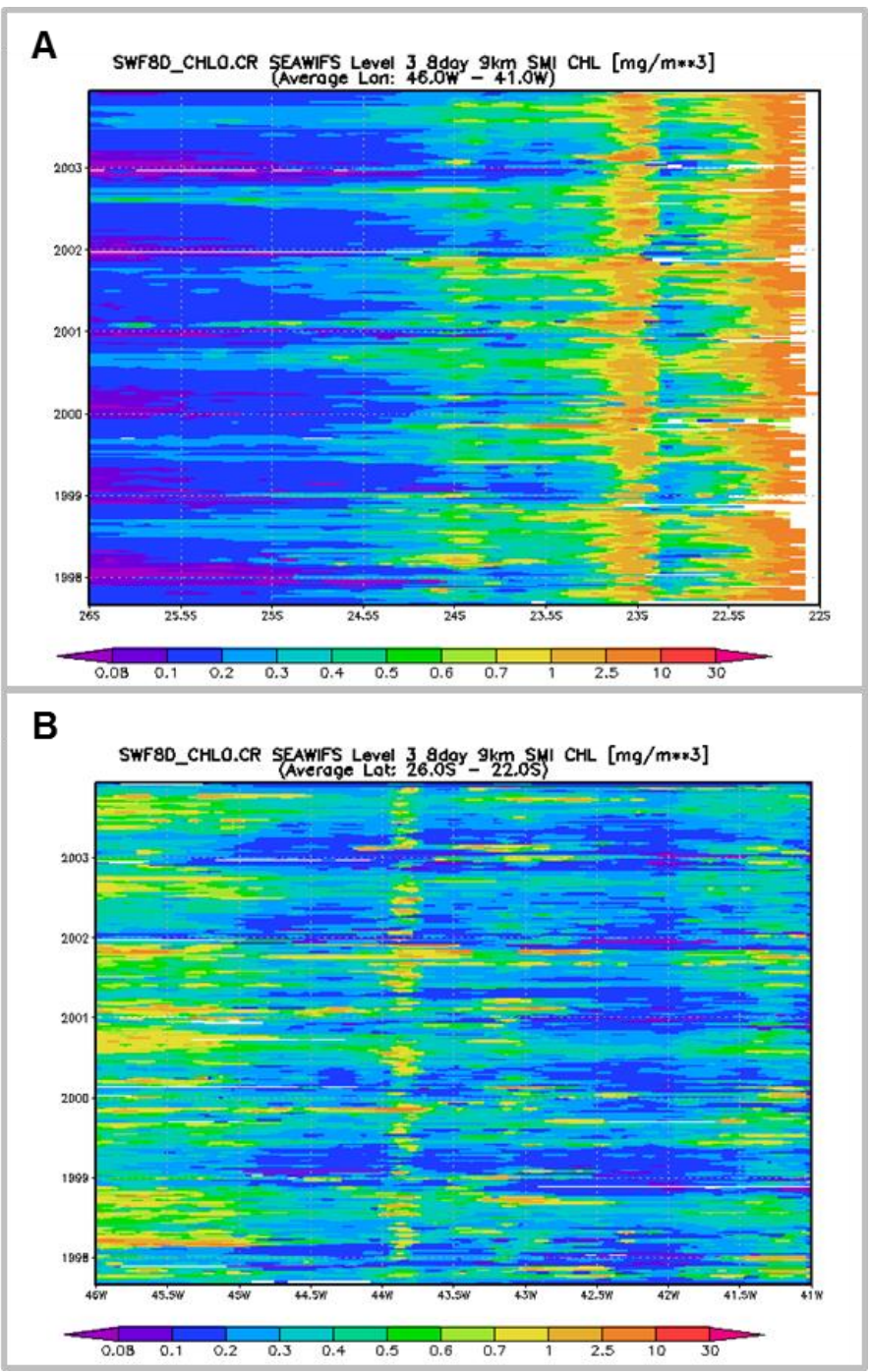

Fig. 3. Zonal-temporal (Hovmöller) diagram for chlorophyll-a mean concentration (mg. $\mathrm{m}^{3}$ ) using SeaWifs sensor: A) between latitudes 22-26 'S (horizontal axis), between 1998 and 2003 (vertical axis); B) between longitudes $46-41^{\circ} \mathrm{W}$ (horizontal axis) between 1998 and 2003 (vertical axis).

In front of São Sebastião Island (374 m water depth), Mahiques et al. (2007) reported Holocene sedimentation rates ranging from 1.4 to $2.6 \mathrm{~cm} . \mathrm{yr}^{-1}$. Thus, our samples $(0-$ $2 \mathrm{~cm}$ ) reflect a sum of oceanographic processes (periodic, episodic or semi-permanent). The "floor-polisher" effect of the meandering of the $\mathrm{BC}$ over the shelf, a semi-permanent feature, can induce the transport of sands from the shelf to the upper slope (Mahiques et al., 2010). The occurrence of sands in the upper slope, below the zone of influence of the $\mathrm{BC}$, may reflect the synergistic effects of the IWBC and changes in the bottom morphology (Marone et al., 2010). 
A

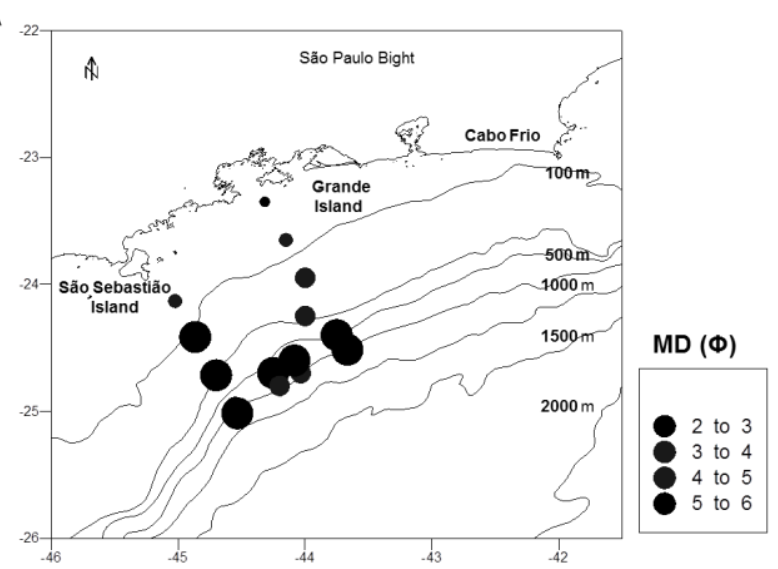

C

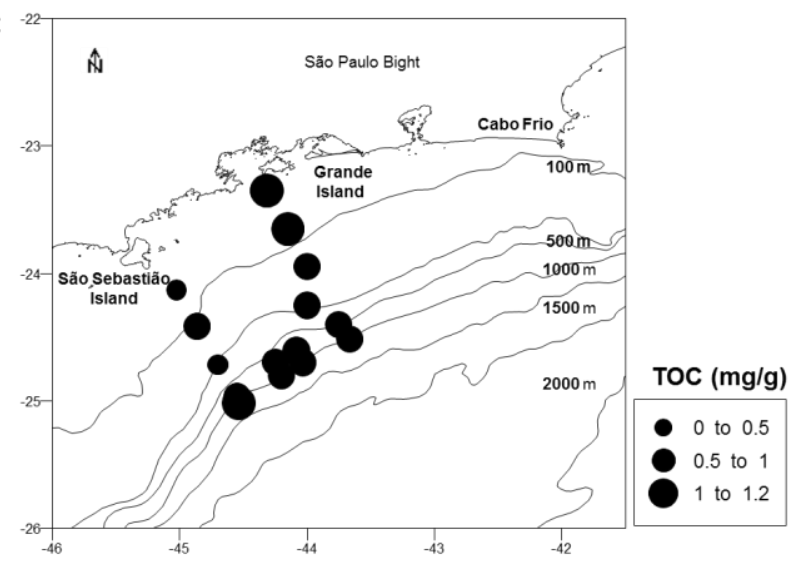

B

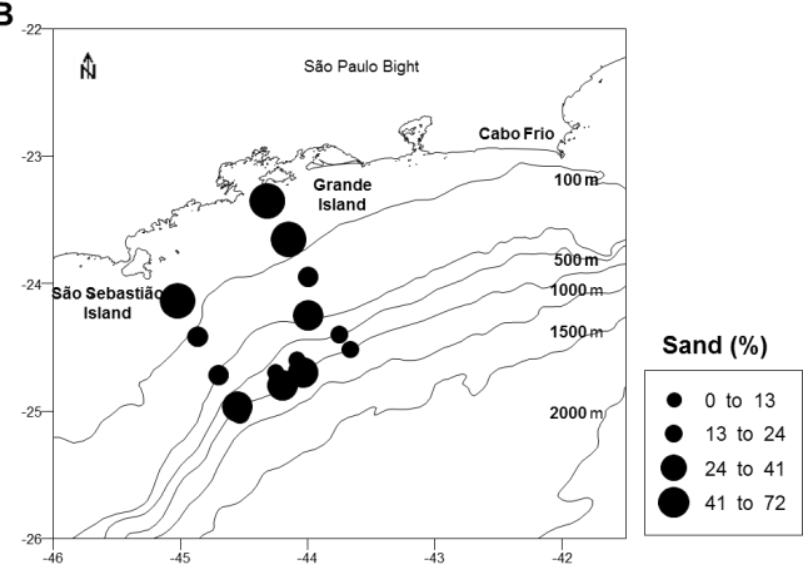

D

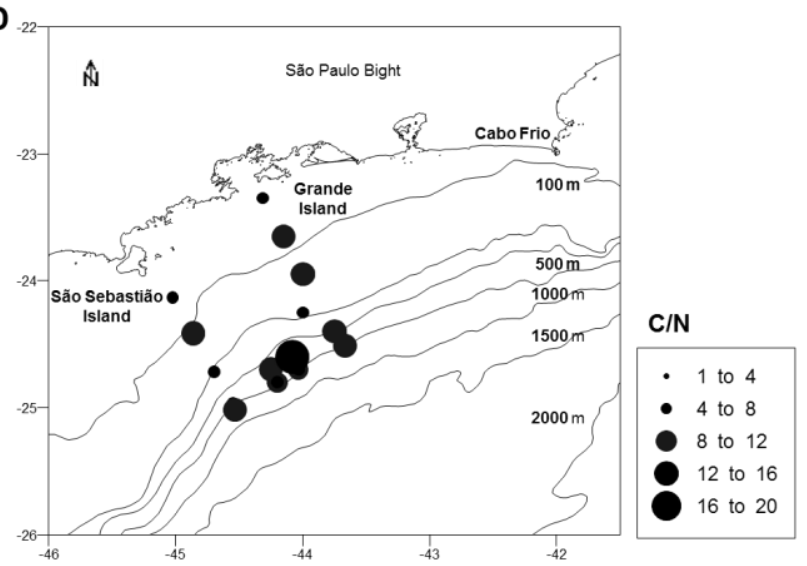

Fig. 4. Distribution of: (A) mean diameter ( $\varphi$ ); (B) sand content (\% weight); (C) total organic carbon (mg/g); and (D) C/ $\mathrm{N}$ ratio values in the sampling sites.

Concentrations of chlorophyll- $a$ may reflect the productivity/phytodetritus input supplied by coastal upwelling (Castro and Miranda 1998), intrusions of nutrientrich SACW (Cerda and Castro, 2013) and shelf break upwelling (Campos et al., 2000; Calado et al., 2010; Palóczy et al., 2013). The zonal-temporal (Hovmöller) diagrams show higher [Chl-a] (0.6-10 mg.m $\left.\mathrm{m}^{-3}\right)$ in the Grande Island area than in São Sebastião Island area (the two regions identified by nMDS analysis based on the studied samples; Figure 7).

In aquatic sedimentary ecosystems, carbon and nitrogen are controlled by the mixing of terrestrial and autochthonous organic matter (Muller, 1977; Rashid and Reinson, 1979; Thornton and McManus, 1994). Accordingly, the $\mathrm{C} / \mathrm{N}$ ratio is used as an indicator of the origin of the sedimentary organic matter. Algae (marine) typically have atomic $\mathrm{C} / \mathrm{N}$ ratios between 4 and 10, whereas vascular land plants have $\mathrm{C} / \mathrm{N}$ ratios of $>20$ (Meyers, 1994).
In the São Sebastião region (stations 1-9), the $\mathrm{C} / \mathrm{N}$ ratio ranged from 6 to 9 (except for station 9) suggesting that the organic matter in these stations is mostly autochthonous (labile), related to phytoplankton and zooplankton sources, newly deposited in the sediment (Bordowskiy, 1965a, b). However, the high value (16.6) observed in station 9 (T3) probably suggests that this site receives continental contributions of organic matter (Meyers, 1994; Mahiques et al., 1999) which should be more degraded (refractory).

In the Grande Island region (stations 10-15), the presence of more labile compounds can be inferred from the $\mathrm{C} / \mathrm{N}$ ratios between 5.5 and 10.2 (Bordowskiy, 1965a, b, Meyers, 1994). High chlorophyll- $a$ concentrations, consequently high fluxes of organic carbon, can explain the high TOC content found in the sediments of T4, which may be associated with high food availability. Therefore, it is possible to infer that in T4 the vertical fluxes of particulate organic matter are higher than in the other transects. 

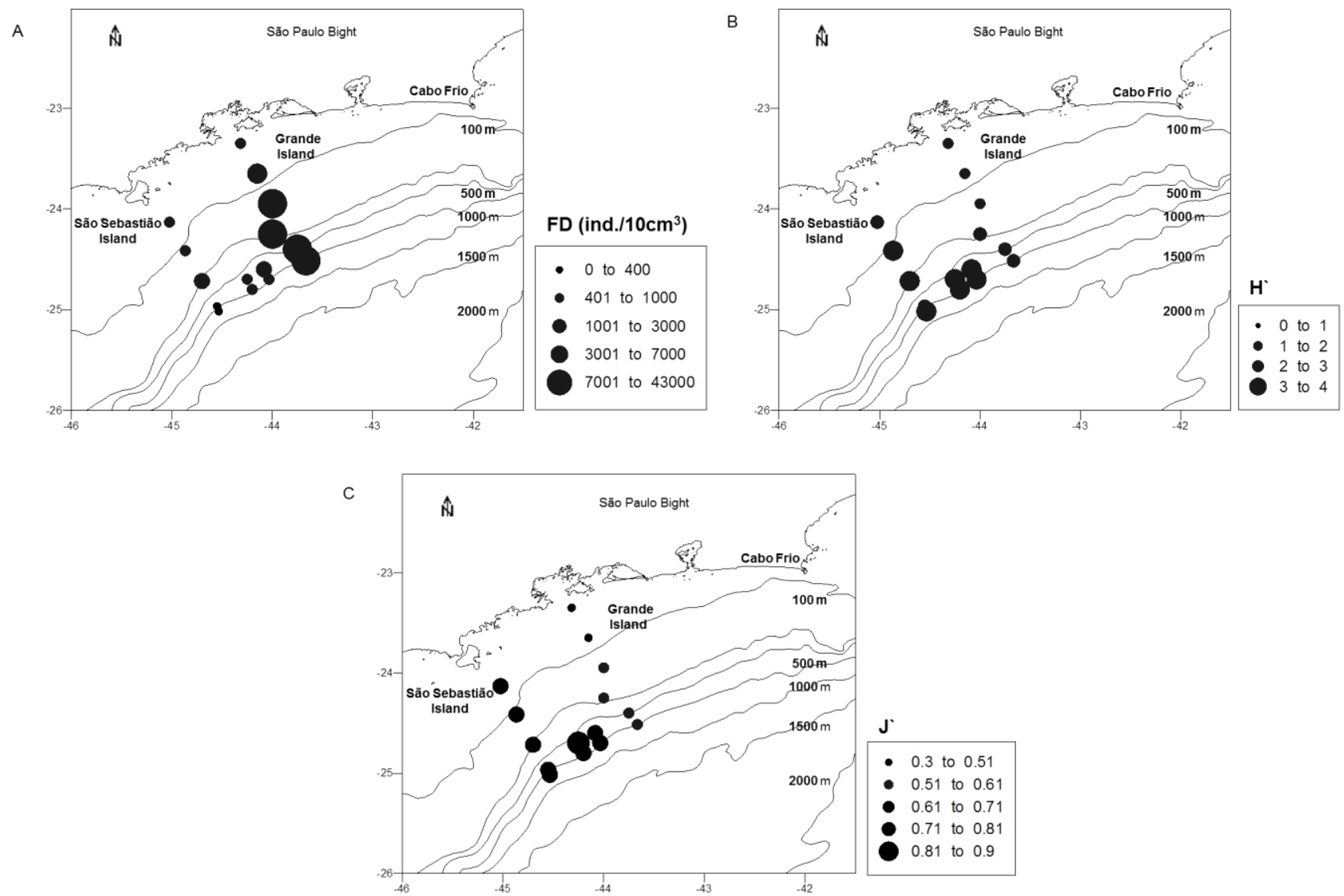

Fig. 5. Distribution of (A) foraminiferal density (FD-ind.10 $\left.\mathrm{cm}^{3}\right)$; (B) diversity $\left(\mathrm{H}^{\prime}\right)$; and $(\mathrm{C})$ equitability $\left(\mathrm{J}^{\prime}\right)$ at the studied sites.

\subsection{São Sebastião Island area (stations 1-9)}

Abundance of benthic foraminifera and the dominance of species is lower but diversity and equitability is comparatively higher in São Sebastião Island area (stations 19) than in the Grande Island area (stations 10-15).

In São Sebastião Island sector, benthic foraminifera assemblages are composed mostly by uvigerinids (7-27 \% such as U. peregrina, Uvigerina auberiana and Uvigerina mediterranea) Bolivinids and Buliminids (<34\%; such as Bolivina fragilis, Bolivina minima, Bolivina ordinaria and Bulimina aculeata) and Cassidulides (up to 2-15\%; such as Cassidulina curvata Cassidulina laevigata/C. carinata; Globocassidulina subglobosa; Evolvocassidulina tenuis), Cibicides/Cibicidoides spp. (0.2-12\%)

In the deeper stations of São Sebastião Island sector increases the relative abundance of Hoeglundina elegans $(<7 \%)$, agglutinated foraminifera (up to $31 \%$; including for instance Ammodiscoides turbinate, Ammoglobigerina globigeriniformis, Cyclammina cancellata, Discammina compressa, Eggerella bradyi,
Haplophragmoides quadratus, Nodulina dentaliniformis, Pseudogaudryina spp., Rhabdammina spp., Rhizammina spp., Sigmoilopsis schlumbergeri, Siphotextularia concava and Textularia pseudogramen). On the contrary some species/groups of species are more common in depths $<765 \mathrm{~m}$, such as: Planulina ariminensis $(<31 \%)$, Rosalina spp. $(<18 \%)$, Miliolids (up to 17\%; such as: Miliolinella circularis and Pyrgo sarsi), Amphicoryna scalaris $(<13 \%$ ) and Pullenia quinqueloba (up to 4\%).

The composition of benthic foraminifera assemblages in São Sebastião Island sector is typical of the open shelf and upper slope environments (Murray, 1991; 2006; Sen Gupta, 1999). The significant relative abundance of uvigerinids, bolivinids, buliminids and cassidulides (Boltovskoy and Wright, 1976; Sen Gupta and Machain-Castillo, 1993; Perez-Cruz and Machain-Castillo, 1990; Levy et al., 1995) and as well as Epistominella exigua (Gooday, 1993), which has been recognized by its opportunistic behavior in relation to food availability, may be linked to pulses of food supply to the sea bottom (Sousa et al., 2006). 

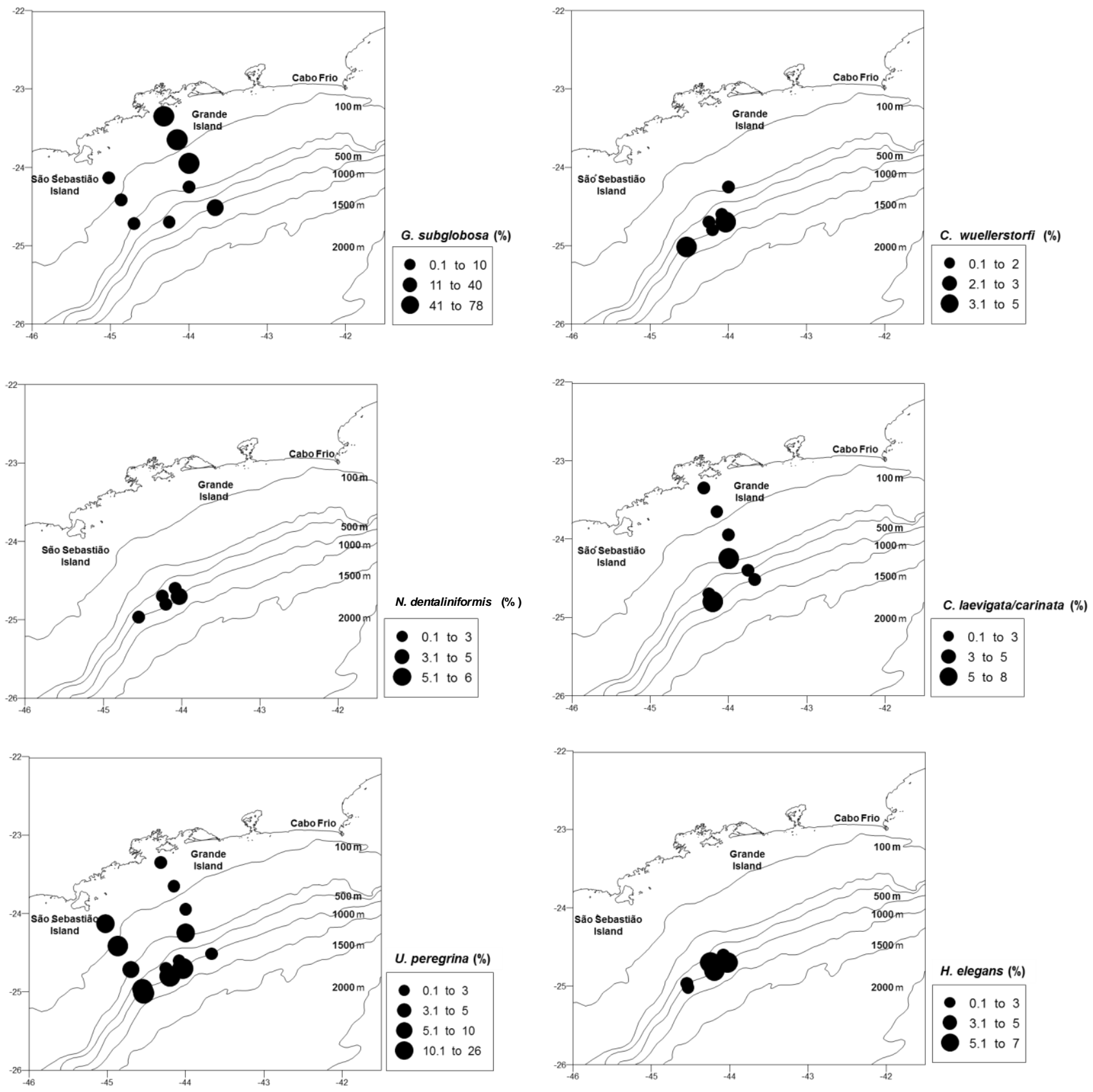

Fig. 6. Maps of distribution of the main species found in the study area: G. subglobosa (\%); C. wuellerstorfi (\%); R. dentaliniformis (\%); C. laevigata/carinata (\%); U. peregrina (\%); H. elegans (\%) (cont).

The relatively high input of organic matter is evidenced by the presence of high productivity and episodic phytodetrital deposition as indicated by the [Chl-a] (0.5-0.6 $\mathrm{mg} / \mathrm{m}^{3}$ ) estimated for this region. São Sebastião Island area is dominated by $U$. peregrina. This species responds to phytodetritus blooms (Fontanier et al., 2003, 2006) and is common in sediments with relatively high phytopigment and lipid concentrations (Duros et al., 2011). There are other species in São Sebastião Island area that are also indicative of episodic phytodetrital deposition such as: P. bulloides (Soma De and Gupta, 2010), H. elegans (Fontanier et al., 2002; Larkin and Gooday, 2009), B. subaenariensis, C. carinata and B. marginata (Eichler et al., 2008; Burone et al., 2011; Duros et al., 2011). 

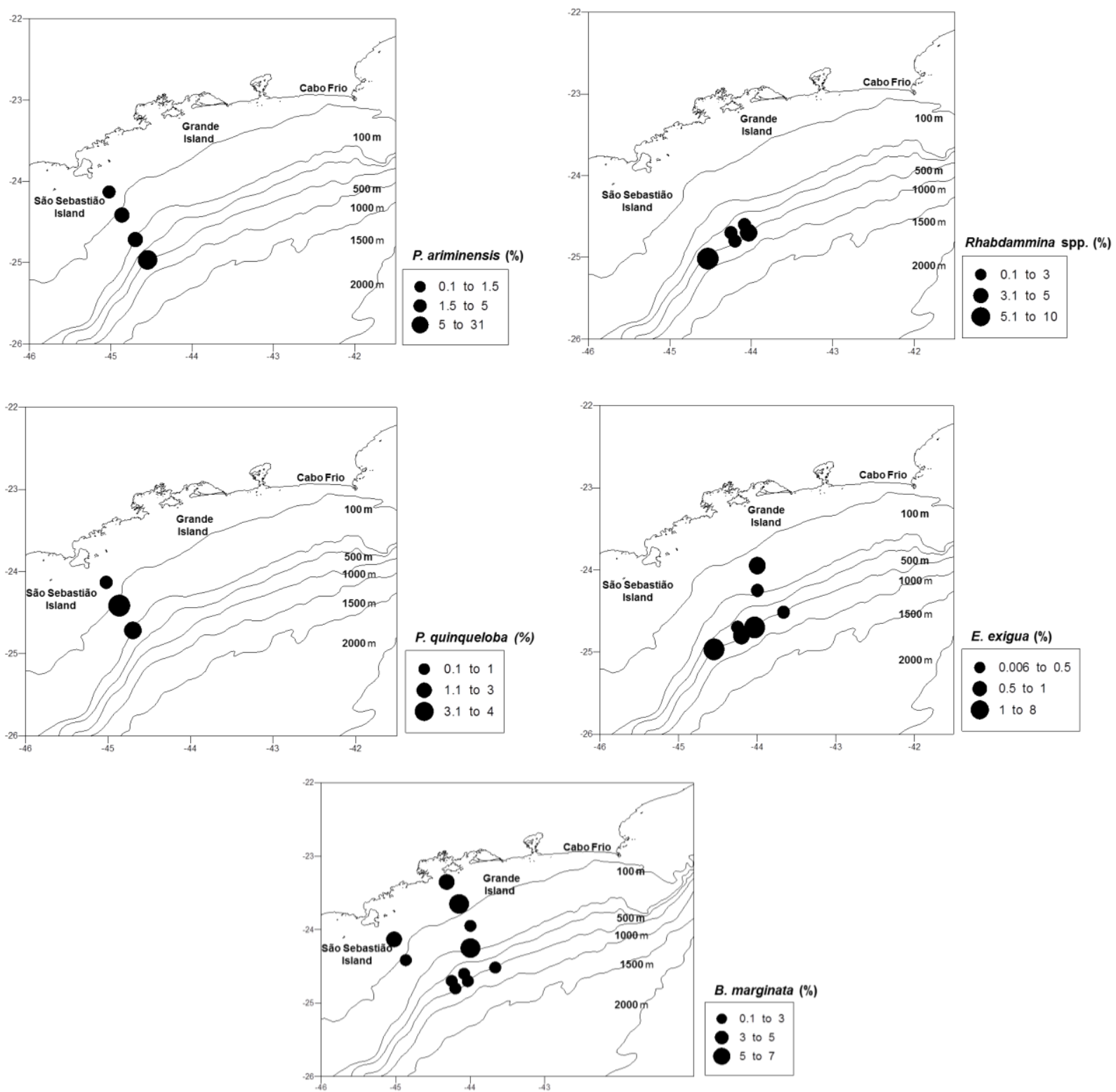

Fig. 6 (cont.). Maps of distribution of the main species found in the study area: P. ariminensis (\%); Rhabdammina spp. (\%); P. quinqueloba $(\%)$; E. exigua (\%); and B. marginata (\%).

Otherwise Planulina ariminensis is typical of high-energy sites (De Stigter et al., 1998). The relatively high percentage of this species, as well as Rosalina spp., Miliolids and Cibicides/Cibicidoides spp. indicates the presence of relatively active currents near the bottom (Martins et al., 2015 and references herein) on the open shelf and shelf beak areas of São Sebastião Island sector.

In fact, Cibicides/Cibicidoides spp. are also frequent in deeper stations of the upper slope. The increased number of agglutinated foraminifera, which generally occupy an epifaunal ecological niche, namely the presence $N$. dentaliniformis (Kaminski, 1985; Hess and Kuhnt, 1996), Textularia pseudogramen (Schönfeld, 2002), may suggest the presence of relatively active currents near the bottom in São Sebastião Island upper slope zone, possibly linked to the activity of IWBC.

However, these currents seems to be not strong enough to generate frequent gravity flow events. This issue is indicated by the increase of the relative abundance of arborescent foraminifera observed at deeper stations of the 
São Sebastião Island sector. Since arborescent foraminifera have limited capacity for recolonization (Hess and Kuhnt, 1996; Koho et al., 2008) and thus they are indicative of low frequency of gravity flow events (Koho et al., 2007, 2008).

In addition, the TOC content increase (up to $10 \mathrm{mg} / \mathrm{g}$ ) in the deeper stations of the São Sebastião Island sector. The $\mathrm{C} / \mathrm{N}$ values indicate that the organic matter present in the sediment is mainly provided by the oceanic productivity. However the exclusive presence of $N$. dentaliniformis in the deeper stations of the São Sebastião Island sector should indicate the occurrence of higher amount of refractory organic matter (Gooday, 1996).

In the open shelf-upper slope stations of São Sebastião Island area the characteristics of the foraminifera assemblages dimension, structure and composition indicate that this region receives intermittently a relatively high flux of organic matter which is corroborated by the [Chl-a] in the water column and TOC content in the sediments.

\subsection{Grande Island area (stations 10-15)}

The sand content is relatively high in the open shelf and slope of Grande Island area which indicates the presence of relatively strong hydrodynamism which should prevent the deposition of organic matter. However the highest values of [Chl-a] $\left(>0.5 \mathrm{mg} \cdot \mathrm{m}^{-3}\right)$ and relatively high concentrations of TOC were recorded in the water column and in the sediments of this region. The $\mathrm{C} / \mathrm{N}$ values indicate the presence of labile compounds. So we can deduce that this zone displays large amount of food availability with good quality even though the prevalence of relatively strong hydrodynamic conditions.

In the Grande Island sector, the highest values of FD and the lowest H' and J' were recorded. The assemblages of benthic foraminifera are dominated by $G$. subglobosa, also including species such as B. marginata, C. laevigata/C. carinata, U. peregrina (Fig. 6; Appendix 1), Cassidulina curvata and Uvigerina mediterranea.

Globocassidulina subglobosa is a shallow infaunal/epifaunal species (Corliss and Chen, 1988; Fontanier et al., 2002). It is considered an opportunistic and suspensive-feeder species (Linke and Lutze, 1993) that is characteristic of sandy sediments affected by strong bottom currents (Mackensen et al., 1995; Schmiedl et al., 1997). This taxon was also reported to be associated with inconstant phytodetrital input to the sea floor (Gooday, 1993; Smart et al., 2010; Duros et al., 2011) and episodic deposition of phytodetritus in the southeastern Brazilian shelf and upper slope (Burone et al., 2011).

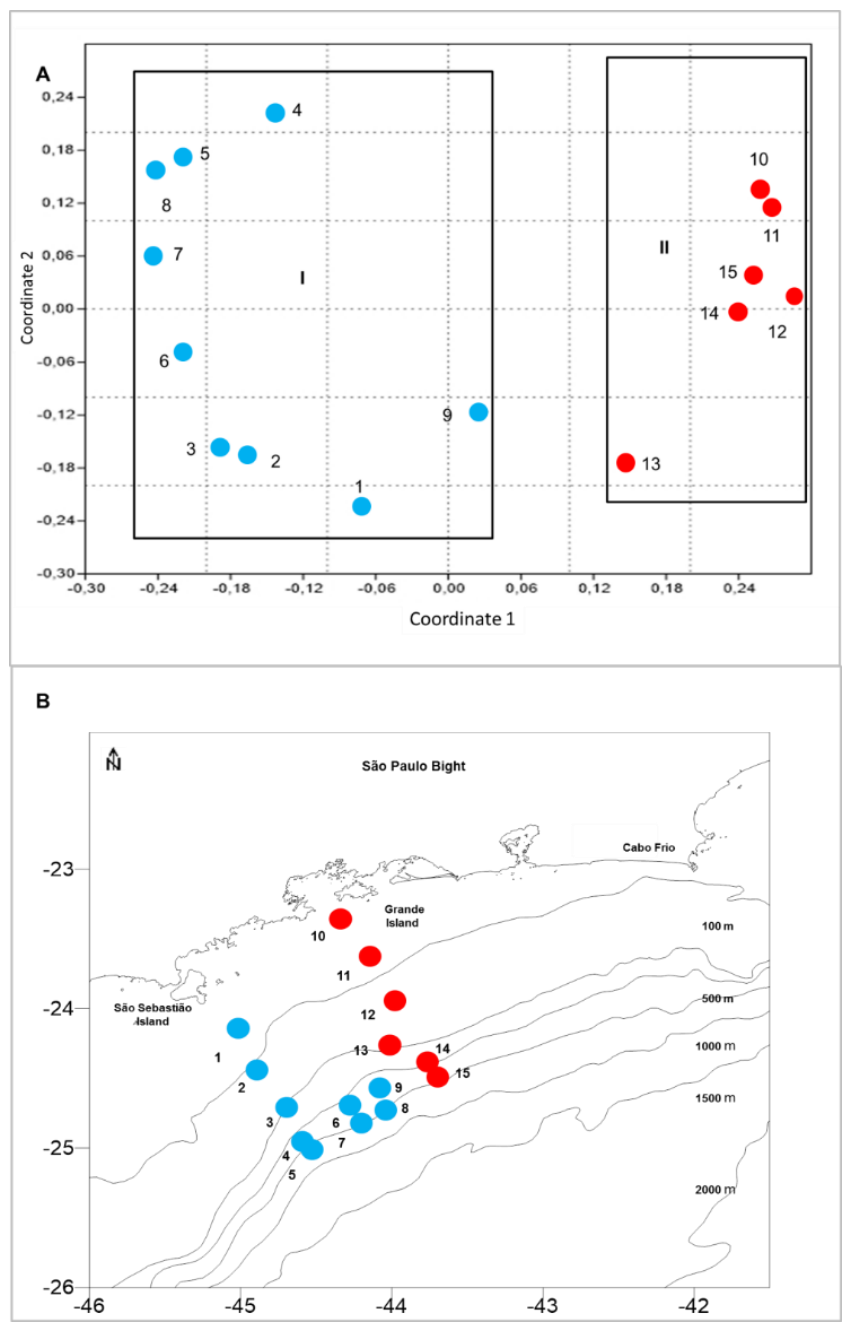

Fig. 7, A) The non-metric multidimensional scaling (nMDS) stress 0.19; B) Location of the 2 identified regions of shortest distance (Region 1: cyan-coloured dot; red-coloured dot).

Cassidulina genus has been recorded in a wide variety of environments, from neritic to bathyal (Miao \& Thunell, 1993), and is recognized for responding to the entry of nutrients into the environment (Nees, 1998). Cassidulina laevigata/C. carinata is related to relatively high productivity (Soma De and Gupta, 2010), as well as B. marginata and $U$. peregrina, as observed by Levy et al. $(1993,1995)$ in the Iberian upwelling system. The presence of $U$. peregrina is related to high productive areas in the ocean and can indicate times of increased fertility (Lutze, 1986). Uvigerinids are in general related to high and rapid uptake of phytodetritus (Nomaki et al., 2006; Woulds et al., 2007; Larkin and Gooday, 2009; Larkin et al., 2014; Enge et al., 2016). 
The high density and low diversity of benthic foraminifera in the open shelf and upper slope of Grande Island area are associated to an essentially opportunistic assemblage composed mostly by G. subglobosa and Cassidulina laevigata/C. carinata Bulimina marginata, C. curvata and uvigerinids which can greatly increase in number during events of phytodetritus flow to the seabed.

The analyzed abiotic results and the characteristics of foraminifera assemblages found at the Grande Island area supports the finding that in this region the benthic environment is influenced by relatively strong hydrodynamic conditions and episodic pulses of organic matter. Nevertheless the flux of organic matter to the bottom is higher in this region than in the São Sebastião Island sector. This is expressed in the size, structure and composition of benthic foraminifera assemblages which includes mainly opportunistic species that quickly answer to good quality food pulses.

In the Grande Island area, high [Chl-a] in the water column and high TOC content in the sediments can be related to the influence of the Cabo Frio upwelling plume (Castro Filho et al., 2006) and shelf break upwelling (Campos et al., 2000; Calado et al., 2010; Palóczy et al., 2013). The southwestward displacement of the Cabo Frio upwelling plume varies in time and can reach the São Sebastião Island (Castro Filho et al., 2006; Yoshinaga et al., 2008). In fact, the lower [Chl-a] in the water column and TOC content in the sediments and the characteristics of the benthic foraminifera assemblages allow us to deduce that the influence of the Cabo Frio upwelling system lose strength in the São Sebastião Island sector.

\section{Conclusion}

The results of this work allow to distinguish two main sectors in the study region of the São Paulo Bight (SW Atlantic): the Grande Island and the São Sebastião Island areas. In both sectors the benthic community seems to be nourished mostly by pulses of organic matter resultant of episodic increases of oceanic productivity. However the flux of organic matter to the bottom seems to be higher in the Grande Island region, which is more influenced by the Cabo Frio upwelling system than in the São Sebastião Island sector.

Despite to be intermittent, this flux of food give place to large benthic foraminifera assemblages characterized by low diversity and equitability and are largely dominated by opportunistic species, such as G. subglobosa in the Grande Island region.
The assemblages of benthic foraminifera and the abiotic variables analyzed in this work, namely the organic matter characteristics suggest that relatively high flux of organic matter also is episodically supplied to the benthic community of the São Sebastião Island sector. However in this region benthic foraminifera assemblages are of smaller dimension, display higher diversity and equitability and lower dominance of species than that of the Grande Island region. These characteristics indicate more stable conditions and lower supply of organic matter to the bottom.

In addition, the relatively high percentage of an arborescent community composed by Rhadammina spp. and Rhizammina spp. found in the deeper slope stations of the São Sebastião Island region, allows us to infer that the sedimentary regime is relatively more stable than in the slope of Grande Island region. The exclusive occurrence of $N$. dentaliniformis in the deeper stations of the São Sebastião Island sector also indicates the presence of a higher amount of refractory organic matter than in Grande Island region.

The results of this work allow to deduce that the supply and availability of food to the bottom is clearly higher in Grande Island area than in the São Sebastião Island sector, as indicated by the abiotic variables and benthic foraminifera assemblages composition.

\section{Acknowledgments}

The authors are indebted to Edilson Faria, Luciana Xavier, Rafael Ferreira, Erika Beltran, Marcelo Rodrigues, Carlos E. Elmadjian and Nancy Taniguchi, who are gratefully acknowledged for the technical support provided. The data used in this work were acquired as part of the activities of NASA's Science Mission Directorate, and are archived and distributed by the Goddard Earth Sciences Data and Information Services Center.

\section{References}

Boltovskoy, E., Guissani, G., Watanabe, S., Wright, R., 1980. Atlas of benthic shelf foraminifera of the southwest Atlantic. Boston-London, Dr W. Junk by Publishers. The Hague.

Boltovskoy, E., Wright, R., 1976. Recent Foraminifera. Dr. W. Junk, The Hague, Boston.

Bordowskiy, O.K., 1965a. Source of organic matter in marine basins. Marine Geology 3, 5-31. doi:10.1016/00253227(65)90003-4

Bordowskiy, O.K., 1965b. Accumulation of organic matter in bottom sediments. Marine Geology 3, 33-82. http://dx.doi:10.1016/0025-3227(65)90004-6

Boyd, P. W., Trull, T.W., 2007. Understanding the export of biogenic particles in oceanic waters: Is there consensus? Progress in Oceanography 72, 276-312. http://dx.doi.org/10.1016/j.pocean.2006.10.007 
Burone, L., B., Sousa, S.H.M., Mahiques, M.M., Valente, P., Ciotti, A., Yamashita, C., 2011. Benthic foraminiferal distribution on the southeastern Brazilian shelf and upper slope. Marine Biology 158, 159-179. http://dx.doi:10.1007/s00227-0101549-7

Calado, L., Silveira, I.C.A, Gangopadhyay, Castro, B.M., 2010. Eddy-induced upwelling off Cape São Tomé (22 ${ }^{\circ} \mathrm{S}$, Brazil). Continental Shelf Research 30 (10), 1181-1188. http://dx.doi:10.1016/j.csr.2010.03.007

Campos, E.J.D., Velhote, D., Silveira, I.C.A., 2000. Shelf break upwelling driven by Brazil Current cyclonic meanders. Geophysical Research Letters 27, 751-754. http://dx.doi: 10.1029/1999GL010502

Campos, E.J.D., Gonçalves, J.E., Ikeda, Y., 1995. Water mass characteristics and geostrophic circulation in the South Brazil Bight: Summer of 1991. Journal Geophysical Research 100, 18537- 18550. http://dx.Doi: 10.1029/95JC01724

Castro Filho, B.M., Lorenzzetti, J.A., Silveira, I.C.A., Miranda, L.B., 2006. Estrutura termohalina e circulação na região entre o Cabo de São Tomé (RJ) e o Chuí (RS). O ambiente oceanográfico da plataforma continental e do talude na região Sudeste-Sul do Brasil. pp. 11-120.

Castro, B.M., 1996. Correntes e massas de água da plataforma continental norte de São Paulo. Tese de Livre Docência. Instituto Oceanográfico da Universidade de São Paulo, São Paulo, 248 p.

Castro, B.M., Miranda, L.B., Miyao, S.Y., 1987. Condições hidrográficas na plataforma continental ao largo de Ubatuba: variações sazonais e em média escala. Boletim Instituto Oceanográfico da Universidade de São Paulo 35, 135-151.

Castro Filho, B.M., Miranda, L.B., 1998. Physical Oceanography of The Western Atlantic Continental Shelf Located Between 4 ${ }^{\circ} \mathrm{N}$ and $34^{\circ} \mathrm{S}$. In: A. Robinson; K. Brink. (org.). The Sea. New York, USA, 11, 209-251.

Cerda, C., Castro, B.M., 2013. Hydrographic climatology of South Brazil Bight shelf waters between São Sebastião $\left(24^{\circ} \mathrm{S}\right)$ and Cabo São Tomé $\left(22^{\circ} \mathrm{S}\right)$. Continental Shelf Research 89, 5-14.

http:/ /dx.doi.org/10.1016/j.csr.2013.11.003i

Conti, L.A., Furtado, V.V., 2006. Geomorfologia da Plataforma Continental do Estado de São Paulo. Revista Brasileira de Geociências 36, 305-312.

Corliss, B.H., Chen, C., 1988. Morphotype patterns of Norwegian Sea deep-sea benthic foraminifera and ecological implications. Geology. 16, 716-719.

De Stigter, H.C., Jorissen, F.J.E Van Der Zwaan, G.J., 1998. Bathymetric distribution and microhabitat partitioning of live (rose Bengal stained) benthic foraminifera along a shelf to bathyal transect in the Southern Adriatic Sea. The Journal of Foramiferal Research 28(1), 40-65.

Den Dulk, M., Reichart, G. J., Memon, G.M., Roelofs, E.M.P.,
Zachariasse, W.J., van der Zwaan, G.J., 1998. Benthic foraminiferal response to variations in surface water productivity and oxygenation in the northern Arabian Sea. Marine Micropaleontology 35, 43-66. http:/ /dx.doi.org/10.1016/S0377-8398(98)00015-2

Duros, P., Fontanier, C., Metzger, E., Pusceddu, A., Cesbron, F., de Stigter, H.C., Bianchelli, S., Danovaro, R., Jorissen, F.J., 2011. Live (stained) benthic foraminifera in the Whittard Canyon, Celtic margin (NE Atlantic). Deep-Sea Research Part I 58, 128-146. http://dx.doi.org/10.1016/j.dsr.2010.11.008

Eichler, P.P.B., Sen Gupta, B.K., Eichler, B.B., Braga, E.S., Campos, E.J., 2008. Benthic foraminiferal assemblages of the South Brazil: Relationship to water masses and nutrient distributions. Continental Shelf Research 28 (13), 1674-1686.

http://dx.doi.org/10.1016/j.csr.2007.10.012

Ellis, B. F., Messina, A. R., 1940. et. seq. Catalog of foraminifera. American Museum of Natural History, Special Publication. New York.

Enge, AJ, Wukovits J, Wanek W, Watzka M, Witte UFM, Hunter W.R., Heinz P., 2016. Carbon and Nitrogen Uptake of Calcareous Benthic Foraminifera along a Depth-Related Oxygen Gradient in the OMZ of the Arabian Sea. Frontiers Microbiology 7, 71 .

http://dx.doi: 10.3389/fmicb.2016.00071

Folk, R.L., Ward, W.C., 1957. Brazos River bar: a study in the significance of grain size parameters. Journal Sedimentary Petrology 27, 3-26.

Fontanier, C., Jorissen, F. J., Lansard, B., Mouret, A., Buscail, R., Schmidt, S., Kerherve', P., Buron, F., Zaragosi, S., Hunault, G., Ernoult, E., Artero, C., Anschutz, P., Rabouille, C., 2008. Live foraminifera from the open slope between Grand Rhone and Petit Rhone Canyons (Gulf of Lions, NW Mediterranean). Deep-Sea Research Part I 55, 1532-1553. http://dx.doi.org/10.1016/j.dsr.2008.07.003

Fontanier, C., Jorissen, F., Anschutz, P., Chaillou, G., 2006. Seasonal variability of benthic foraminiferal faunas at $1000 \mathrm{~m}$ depth in the Bay of Biscay. The Journal of Foraminiferal Research 36, 61-76. http://dx.doi: 10.2113/36.1.61

Fontanier, C., Jorissen, F.J., Chaillou, G., David, C., Anschutz, P., Lafon, V., 2003. Seasonal and interannual variability of benthic foraminiferal faunas at $550 \mathrm{~m}$ depth in the Bay of Biscay. DeepSea Research Part I 50, 457-494.

Fontanier, C., Jorissen, F., Licari, L., Alexandre, A., Anschutz, P., Carbonel, P., 2002. Live benthic foraminiferal faunas from the Bay of Biscay: faunal density, composition and microhabitats. Deep-Sea Research Part I 49, 751-785. http://dx.doi.org/10.1016/S0967-0637(01)00078-4

Furtado, V.V., Bonetti, Filho J., Conti, L.A., 1996. Paleo river morphology and sea level changes at southeastern Brazilian continental shelf. Anais da Academia Brasileira de Ciências 68, 163- 169. 
Gooday, A.J., 1996. Epifaunal and shallow infaunal foraminiferal communities at three abyssal NE Atlantic sites subject to differing phytodetritus input regimes. Deep-Sea Research Part I 43, 1395-1421. http:// dx.doi:10.1016/S0967-0637(96)000726

Gooday, A.J., 1993. Deep-sea benthic foraminifera species which exploit phytodetritus: characteristic features and controls on distribution. Marine Micropaleontology 22, 187-205. http://dx.doi:10.1016/0377-8398(93)90043-W

Gyllencreutz, R., Mahiques, M.M., Alves, D.V.P., Wainer, I.K.C., 2010. Mid- to late-Holocene paleoceanographic changes on the southeastern Brazilian shelf based on grain size records. Holocene. 20 (6), 863-875.

Hammer, Ø., Harper, D.A.T., Ryan, P.D., 2001. PAST: Paleontological statistics software package for education and data analysis. Palaeontologia Electronica 4(1), 4-9. http://palaeo-electronica.org/2001_1/past/issue1_01.htm

Harloff, J., Mackensen, A., 1997. Recent benthic foraminiferal associations and ecology of the Scotia Sea and Argentine Basin. Marine Micropaleontology 31, 1-29. http:/ dx.doi.org/10.1016/S0377-8398(96)00059-X

Hayward, B.W., T. Cedhagen, M. Kaminski and O. Gross., 2016. World Foraminifera database. Accessed at http://www.marinespecies.org/foraminifera, accessed at 9 October 2016.

Heinz, P., Hemleben, CH., 2003. Regional and seasonal variations of recent benthic deep-sea foraminifera in the Arabian Sea. Deep-Sea Research Part I 50, 435-447. http:/ /dx.doi.org/10.1016/S0967-0637(03)00014-1

Hess, S., Jorissen, F.J., 2009. Distribution patterns of living benthic foraminifera from Cap Breton canyon, Bay of Biscay: faunal response to sediment instability. Deep-Sea Research Part I 56, 1555-1578. http://dx.doi.org/10.1016/j.dsr.2009.04.003

Hess, S., Kuhnt, W., 1996. Deep-sea benthic foraminiferal recolonization of the $1991 \mathrm{Mt}$. Pinatubo ash layer in the South China Sea. Marine Micropaleontology 28, 171- 197. http:/ /dx.doi.org/10.1016/0377-8398(95)00080-1

Jones, R.W., 1994. The Challenger foraminifera. Oxford University Press, USA. First Edition.

Jorissen, F., Fontanier, C., Thomas, E., 2007. Paleoceanographical proxies based on deep-sea benthic foraminiferal assemblage characteristics. In: Hillaire-Marcel and C. Vernal, A. (ed.) Proxies in Late Cenozoic Paleoceanography: Pt. 2: Biological tracers and biomarkers, Elsevier, pp. 263-326.

Jorissen, F.J., Buzas, H., Culver, S., Kuehl, S., 1994. Vertical distribution of living benthic Foraminifera in submarine canyons off New Jersey. The Journal of Foraminiferal Research 24, 28-36. DOI: 10.2113 /gsjfr.24.1.28

Kaminski, M.A., 1985. Evidence for control of abyssal agglutinated community structure by substrate disturbance: results from the HEBBLE Area. Marine Geology 66, 113-131. DOI:10.1016/0025-3227(85)90025-8
Klaas, C., Archer, D., 2002. Association of sinking organic matter with various types of mineral ballast in the deep sea: Implications for the rain ratio. Global Biogeochemical Cycles 16. DOI: $10.1029 / 2001 G B 00176$

Koho, K.A., García, R., de Stigter, H.C., Epping, E., Koning, E., Kouwenhoven, T.J., Van Der Zwaan, G.J., 2008. Sedimentary labile organic carbon and pore water redox control on species distribution of benthic foraminifera: a case study from LisbonSetúbal Canyon (southern Portugal). Progress in Oceanography $\quad 79 \quad$ (1), 55-82. http://dx.doi.org/10.1016/j.pocean.2008.07.004

Koho, K.A., Kouwenhoven, T.J., DE Stigter, H.C., Van Der Zwaan, G.J., 2007. Benthic foraminifera in the Nazaré canyon, Portuguese continental margin: sedimentary environments and disturbance. Marine Micropaleontology 66, 27-5.

http://dx.doi.org/10.1016/j.marmicro.2007.07.005

Larkin, K.E., Gooday, A.J., 2009. Foraminiferal faunal responses to monsoon-driven changes in organic matter and oxygen availability at $140 \mathrm{~m}$ and $300 \mathrm{~m}$ water depths in the NE Arabian Sea. Deep Sea Research Part II 56, 403-421. http://dx.doi: 10.1016/j.dsr2.2008.05.037

Larkin, K.E., Gooday, A.J., Woulds, C., Jeffreys, R., Schwartz, M., Cowie, G., Whitcraft, C. Levin, L., Dick, J. R., Pond, D.W., 2014. Uptake of algal carbon and the synthesis of an "essential" fatty acid by Uvigerina ex. gr. semiornata (Foraminifera) within the Pakistan margin oxygen minimum zone: evidence from fatty acid biomarker and 13C tracer experiments. Biogeosciences 11, 3729-3738. http://dx.doi: 10.5194/bg-113729-2014

Levy, A., Mattieu, R., Poignant, A., Rosset-Moulinier, M., Ubaldo, M., Lebreiro, S., 1995. Foraminifères Actuels de la Merge Continental Portuguaise e Inventaire et Distribuicion, vol. 32. Memórias do Instituto Geológico e Mineiro, Lisboa, Portugal.

Levy, A., Mathieu, R., Poignant, A., Rosset-Moulinier, M., Ubaldo, M.L., Ambroise, D., 1993. Recent foraminifera from the continental margin of Portugal. Micropaleontology 39, 75-87.

Linke, P., Lutze, G.F., 1993. Microhabitat preferences of benthic foraminifera -A static concept or a dynamic adaptation to optimize food acquisition? Marine Micropaleontology 20, 215234.

Loeblich, A.R., Tappan, H., 1988. Foraminiferal genera and their classification, first ed. Van Nostrand Reinhold, New York.

Lutze, G.F., 1986. Uvigerina species of the Eastern North Atlantic. Utrecht Micropaleontological Bulletins 22 (35), 21-46.

Mackensen, A., Schmiedl, G., Harloff, J., Giese, M., 1995. Deepsea foraminifera in the South Atlantic Ocean: ecology and assemblage generation. Micropaleontology 41 (4), 342-358.

Mahiques, M.M., Sousa, S.H.M., Furtado, V.V., Tessler, M. G., Toledo, F.A.L., Burone, L., Figueira, R.C.L., Klein, D.A., Martins, C.C., Alves, D.P.V., 2010. The Southern Brazilian shelf: general characteristics, quaternary evolution and 
sediment distribution. Brazilian Journal of Oceanography 58 (n.spe2), 25-34.

http://dx.doi.org/10.1590/S1679-87592010000600004

Mahiques, M.M., Fukumoto, M.M., Silveira I.C.A., Figueira, R.C.L., Bícego, M.C., Lourenço R.A., Sousa S.H.M., 2007. Sedimentary changes on the Southeastern Brazilian upper slope during the last 35,000 years. Anais da Academia Brasileira de Ciências 79, 171-181. http://dx.doi.org/10.1590/S000137652007000100018

Mahiques, M.M., Tessler, M. G., Ciotti, A.M., Silveira, I.C.A., Sousa, S. H. D. E., Figueira, R. C.L., Tassinari, C.C. G., Furtado, V.V., Passos, R.F., 2004. Hydrodynamically driven patterns of recent sedimentation in the shelf and upper slope off Southeast Brazil. Continental Shelf Research 24 (15), 16851697. http://dx.doi.org/10.1016/j.csr.2004.05.013

Mahiques, M.M., Silveira, I.C.A., Sousa, S.H.M., Rodrigues, M., 2002. Post-LGM sedimentation on the outer shelf-upper slope of the northermost part of São Paulo Bight, southeastern Brazil. Marine Geology 181, 387-400. http://dx.doi.org/10.1016/S0025-3227(01)00225-0

Mahiques, M.M., Mishima, Y., Rodrigues, M., 1999. Characteristics of the sedimentary organic matter on the inner and middle continental shelf between Guanabara Bay and São Francisco do Sul, south-eastern Brazilian margin. Continental Shelf Research 19, 775-798. http://dx.doi: 10.1016/S02784343(98)00105-8

Marone, E., Knoppers, B.A., Souza, W.F.L. Silveira, I.C., Godoi, S.S., 2010. The Brazil Current: Physical-Biogeochemical Domains. In: Liu, K.K., Atkinson, L., Quinones, R. and TalaueMcmanus, L. (eds.). Carbon and Nutrients Fluxes in Continental Margins. Springer. pp. 153-169.

Martins, M.V.A., Victor Quintino, V., Tentúgal, R.M., Frontalini, F., Miranda, P., Laut, L.L.M., Martins, R., Rodrigues, A.M., 2015. Characterization of bottom hydrodynamic conditions on the central western Portuguese continental shelf based on benthic foraminifera and sedimentary parameters Marine Environmental Research 109, 52-68. http://dx.doi.org/10.1016/j.marenvres.2015.06.006

Martins, M.V.A., Gomes, V.C.R.D., 2004. Foraminíferos da margem Continental NW Ibérica: sistemática, ecologia e distribuição. First ed, Gomes, C.S.F. (ed.), Aveiro University, Portugal.

Mazzini, P.L.F., Barth, J.A., 2013. A comparison of mechanisms generating vertical transport in the Brazilian coastal upwelling regions. Journal of Geophysical Research 118 (11), 5977-5993. DOI: 10.1002/2013JC008924

Meyers, P.A., 1994. Preservation of elemental and isotopic source identification of sedimentary organic-matter. Chemical Geology 114 (3-4), 289-302. http://dx.doi:10.1016/00092541(94)90059-0

Miao, Q., Thunell, R.C., 1993. Recent deep-sea benthic foraminiferal distributions in the south China and Sulu Seas.
Marine Micropaleontology 22, 1-32. http://dx.doi:10.1016/0377-8398(93)90002-F

Miranda, L.B., 1985. Forma de correlação TS de massa de água das regiões costeira e oceânica entre o Cabo de São Tomé (RJ) e a Ilha de São Sebastião (SP), Brasil. Boletim Instituto Oceanográfico da Universidade de São Paulo. 33, 105-119.

Morigi, C., Jorissen, F.J., Gervais, A., Guichard, S., Borsetti, A. M., 2001. Benthic foraminiferal faunas in surface sediments off NW Africa: relationship with organic flux to the ocean floor. The Journal of Foraminiferal Research 31, 350-368. http://dx.doi: 10.2113/0310350

Muller, P.J., 1977. C/N ratios in Pacific deep sea sediments: Effect of inorganic ammonium and organic nitrogen compounds sorbed by clay. Geochimica et Cosmochimica Acta 41, 765776.

http://dx.doi:10.1016/0016-7037(77)90047-3

Murray, J.W., 2006. Ecology and Applications of Benthic Foraminifera. Cambridge, UK, Cambridge University Press.

Murray, J.W., 2003. An illustrated guide to the benthic foraminifera of the Hebridean shelf, West of Scotland, with notes on their mode of life. Palaeontologia Electronica 5(1):31pp, http://palaeo-

electronica.org/paleo/2002_2/guide/issue2_02.htm

Murray, J.W., 1991. Ecology and palaeoecology of benthic foraminifera. London, Longman Scientific \& Technical.

Nees, S., 1998. Ground truth in palaeoceanography - good news from the sea floor. In: International Conference on Palaeoceanography, 6, Lisboa, Portugal, Proceedings, 5p.

Nomaki, H., Heinz, P., Nakatsuka, T., Shimanaga, M., Ohkouchi, N., Ogawa, N., Kogure, K., Ikemoto, E., Kitazato, H., 2006. Different ingestion patterns of ${ }^{13} \mathrm{C}$-labeled bacteria and algae by deep-sea benthic foraminifera. Marine Ecology Progress Series 310, 95-108. http://dx.doi:10.3354/meps310095

Palóczy, A., Silveira, I.C.A., Castro, B.M., Calado, L., 2013. Coastal upwelling off Cape São Tomé $\left(22^{\circ} \mathrm{S}\right.$, Brazil): The supporting role of deep ocean processes. Continental Shelf Research 89, 38-50. http://dx.doi: 10.1016/j.csr.2013.09.005

Perez-Cruz, L.L., Machain-Castillo, M.L., 1990. Benthic foraminifera of the oxygen minimum zone, continental shelf of the Gulf of Tehuantepec, Mexico. The Journal Foraminiferal Research 20, 312-325. http://dx.doi: 10.2113/gsjfr.20.4.312

Pielou, E.C., 1975. Ecological diversity. New York, John Wiley.

Rashid, M.A., Reinson, G.E., 1979. Organic matter in surficial sediments of the Miramichi Estuary, New Brunswick, Canada. Estuarine, Coastal and Shelf Science 8, 23-36. http://dx.doi: 10.1016/0302-3524(79)90103-8

Rodrigues, R.R., Lorenzetti., J.A., 2001. A numerical study of the effects of bottom topography and coastline geometry on the southeast Brazilian coastal upwelling. Continental Shelf Research 21, 371-393. DOI: 10.1016/S0278-4343(00)00094-7 
Saldanha-Corrêa, F.M.P., Gianesella, S.M.F., 2008. Produção primária e fitoplâncton. In: A.M.S. Pires-Vanin. (Org.). Oceanografia de um Ecossitema Subtropical: Plataforma de São Sebastião. 1 ed. São Paulo: Editora da Universidade de São Paulo- EDUSP, 1, 223-251.

Schmiedl, G., Bovée, F., Buscail, R., Hemleben, C., Medernach, L., Picon, P., 2000. Trophic control of benthic foraminiferal abundance and microhabitat in the bathyal Gulf of Lions, western Mediterranean Sea. Marine Micropaleontology 40, 167-188. http://dx.doi.org/10.1016/S0377-8398(00)00038-4

Schmiedl, G., Mackensen, A., Müller P.J., 1997. Recent benthic foraminifera from the eastern South Atlantic Ocean: Dependence on food supply and water masses. Marine Micropaleontology 32, 249-289. http:/ /dx.doi.org/10.1016/S0377-8398(97)00023-6

Schönfeld, J., 2002. A new benthic foraminiferal proxy for near bottom current velocities in the Gulf of Cadiz, northeastern Atlantic Ocean. Deep-Sea Research Part I 49: 1853-1875. http://dx.doi.org/10.1016/S0967-0637(02)00088-2

Sen Gupta, B.K., 1999. Introduction to modern Foraminifera. In: Sen Gupta, B. K. (ed.) Modern foraminifera. Kluwer Academic Publishers, p. 3-6.

Sen Gupta, B., Machain-Castillo, M., 1993. Benthic foraminifera in oxygen-poor habitats. Marine Micropaleontology 20, 183-201. http://dx.doi:10.1016/0377-8398(93)90032-S

Shannon, C.E., 1948. A mathematical theory of communication. Bell System Techical Journal 27, 379-423.

Signorini, S.R., Miranda, L.B., Evans, D.L., Stevenson, M.R., Inostroza, H.M., 1989. Corrente do Brasil: estrutura geotérmica entre $19^{\circ}$ e $25^{\circ} \mathrm{S}$ e circulação geostrófica. Boletim Instituto Oceanográfico da Universidade de São Paulo 37, 33-49.

Silveira, I.C.A., Lima, J.A.M., Schmidt, A.C.K., Ceccopieri, W., Sartori, A., Franscisco, C.P.F., Fontes, R.F.C., 2008. Is the meander growth in the Brazil Current system off Southeast Brazil due to baroclinic instability? Dynamics Atmospheres Oceans 45, 187-207. http://dx.doi.org/10.1016/j.dynatmoce.2008.01.002

Silveira, I.C.A., 2007. O Sistema Corrente do Brasil na Bacia de Campos, RJ. Instituto Oceanográfico Universidade de São Paulo. São Paulo, 160 p.

Silveira, I.C.A., Schmidt, A.C.K., Campos, E.J.S., Godoi, S.S., Ikeda, Y., 2000. A Corrente do Brasil ao largo da costa leste brasileira. Revista Brasileira de Oceanografia 48, 171-183. http:/ /dx.doi.org/10.1590/S1679-87592000000200008

Smart, C.W., Waelbroeck, C., Michel, E., Mazaud, A., 2010. Benthic foraminiferal abundance and stable isotope changes in the Indian Ocean sector of the Southern Ocean during the last 20 kyr: Paleoceanographic implications. Palaeogeography, Palaeoclimatology, Palaeoecology 297 (3-4), 537-548.

http://dx.doi.org/10.1016/j.palaeo.2010.08.011
Soma De, Gupta, A.K., 2010. Deep-sea faunal provinces and their inferred environments in the Indian Ocean based on distribution of Recent benthic foraminifera Soma. Palaeogeography, Palaeoclimatology, Palaeoecology 291, 429_ 442.

http://dx.doi:10.1016/j.palaeo.2010.03.012

Sousa, S.H.M., Passos, R.F., Fukumoto, M., Silveira, I.C.A., Figueira, R.C.L., Koutsoukos, E.A.M., Mahiques, M.M., Rezende, C.E., 2006. Mid-lower bathial benthic foraminifera of the Campos Basin, Southeastern Brazilian margin: Biotopes and controlling ecological factors. Marine Micropaleontology 61, 40-57. http://dx.doi.org/10.1016/j.marmicro.2006.05.003

Soutelino, R.G., Gangopadhyay, A., Silveira, I.C.A., 2013. The roles of vertical shear and topography on the eddy formation near the site of origin of the Brazil Current. Continental Shelf Research 70, 46-6. http://dx.doi.org/10.1016/j.csr.2013.10.001

Thornton, S.F., McManus, J., 1994. Application of Organic Carbon and Nitrogen Stable Isotope and C/N Ratios as Source Indicators of Organic Matter Provenance in Estuarine Systems: Evidence from the Tay Estuary, Scotland. Estuarine, Coastal and Shelf Science 38, 219-233. http://dx.doi:10.1006/ecss.1994.1015

van Morkhoven, F.P.C.M., Berggren, W.A., Edwards, A.S., 1986. Cenozoic cosmopolitan deep-water benthic foraminifera. Bulletin du Centre de Recherches Elf Exploration-Production Elf-Aquitaine 11, 421.

Velhote, D., 1998: Modelagem numérica da ressurgência da quebra de plataforma induzida por vórtices ciclônicos da Corrente do Brasil na Bacia de Santos, Dissertação de Mestrado. Instituto Oceanográfico. Universidade de São Paulo, 134p.

Viana, A.R., Faugères, J.C., Kowsmann, R.O., Lima, J.A.M., Cada, L.F.G., Rizzo, J.G., 1998. Hydrology, morphology and sedimentology of the Campos continental margin, offshore Brazil. Sedimentary Geology 115, 133-157. http://dx.DOI:10.1016/S0037-0738(97)00090-0

Woulds, C., Cowie, G.L., Levin, L.A., Andersson, J.H., Middelburg, J.J., Vandewiele, S., Lamont, P.A., Larkin, K.E., Gooday, A.J., Schumacher, S., Whitcraft, C., Jeffreys, R. M., Schwartz, M., 2007. Oxygen as a control on seafloor biological communities and their roles in sedimentary carbon cycling. Limnology Oceanography 52, 1698-1709. http://dx.doi: 10.4319/lo.2007.52.4.1698

Yassini, I., Jones., B.G., 1995. Recent foraminifera and ostracoda from estuarine and shelf environments on the southeastern coast of Australia. Wollongong: University of Wollongong Press.

Yoshinaga, M.Y., Sumida, P.Y.G., Wakeham, S.G., 2008. Lipid biomarkers in surface sediments from an unusual coastal upwelling area from the SW Atlantic Ocean. Organic 
Geochemistry

39 , doi.org/10.1016/j.orggeochem.2008.07.006

Zembruscki, S.G., 1979. Geomorfologia da margem continental sul brasileira e das bacias oceânicas adjacentes. In: Chaves,

1385-1399.
H.A.F. (ed.), Geomorfologia da margem continental brasileira e das bacias oceânicas adjacentes. Série Projeto REMAC, PETROBRAS-CENPES-DINTEP. Rio de Janeiro, 7, 129177. 
Appendix 1. Percentage of foraminiferal species in the studied samples ( $>3 \%$ in at least one station).

\begin{tabular}{|c|c|c|c|c|c|c|c|c|c|c|c|c|c|c|c|}
\hline Station & 1 & 2 & 3 & 4 & 5 & 6 & 7 & 8 & 9 & 10 & 11 & 12 & 13 & 14 & 15 \\
\hline $\begin{array}{l}\text { Ammodiscoides turbinatus Cushman, } \\
1909\end{array}$ & 0.00 & 0.00 & 0.00 & 1.15 & 2.72 & 1.23 & 1.43 & 2.44 & 0.74 & 0.00 & 0.00 & 0.00 & 0.02 & 0.01 & 0.00 \\
\hline Amphicoryna scalaris (Batsch 1791) & 0.00 & 4.37 & 12.93 & 0.00 & 0.00 & 0.00 & 0.00 & 0.00 & 0.00 & 0.00 & 0.00 & 0.00 & 0.00 & 0.00 & 0.00 \\
\hline $\begin{array}{l}\text { Anomalinoides incrassatus (Fichtel \& } \\
\text { Moll, 1798) }\end{array}$ & 0.00 & 0.00 & 0.00 & 0.29 & 0.39 & 2.01 & 0.29 & 0.61 & 0.00 & 0.00 & 0.00 & 0.00 & 6.16 & 0.00 & 0.03 \\
\hline $\begin{array}{l}\text { Bolivina minima Phleger \& Parker, } \\
1951\end{array}$ & 0.43 & 0.00 & 0.00 & 0.00 & 0.00 & 0.11 & 0.00 & 0.00 & 0.00 & 0.12 & 0.26 & 0.15 & 0.26 & 5.32 & 0.00 \\
\hline $\begin{array}{l}\text { Bolivina ordinaria Pheleger \& Parker, } \\
1952\end{array}$ & 1.73 & 0.22 & 0.00 & 0.00 & 0.00 & 6.38 & 10.88 & 0.00 & 14.65 & 0.00 & 0.00 & 0.92 & 1.40 & 9.98 & 3.77 \\
\hline $\begin{array}{l}\text { Brizalina fragilis (Phleger \& Parker, } \\
\text { 1951) }\end{array}$ & 6.47 & 0.44 & 0.00 & 0.00 & 0.00 & 0.22 & 0.43 & 0.00 & 1.39 & 1.20 & 0.00 & 0.62 & 0.14 & 2.99 & 0.00 \\
\hline Brizalina spp. & 7.77 & 0.00 & 0.00 & 1.44 & 0.00 & 3.02 & 3.44 & 0.81 & 14.65 & 0.84 & 0.39 & 1.39 & 1.11 & 0.00 & 10.90 \\
\hline Bulimina aculeata d'Orbigny, 1826 & 0.00 & 0.00 & 0.00 & 0.87 & 1.94 & 4.70 & 0.57 & 0.81 & 0.09 & 0.00 & 0.00 & 0.00 & 0.00 & 0.00 & 0.01 \\
\hline Bulimina marginata d' Orbibny 1826 & 4.53 & 1.75 & 0.00 & 0.00 & 0.00 & 1.23 & 1.00 & 0.61 & 2.75 & 3.85 & 6.84 & 2.77 & 5.22 & 0.00 & 2.15 \\
\hline $\begin{array}{l}\text { Cassidulina curvata Phleger \& } \\
\text { Parker, } 1951\end{array}$ & 0.00 & 0.87 & 0.00 & 0.00 & 0.00 & 0.11 & 0.43 & 0.00 & 5.58 & 0.00 & 0.39 & 0.15 & 14.89 & 9.64 & 2.52 \\
\hline $\begin{array}{l}\text { Cassidulina laevigata d' Orbigny, } \\
1826 / \text { C. carinata (Silvestri, 1896) }\end{array}$ & 0.00 & 0.00 & 0.00 & 1.73 & 1.17 & 0.11 & 7.73 & 0.00 & 0.00 & 0.12 & 0.26 & 2.00 & 21.61 & 0.66 & 1.27 \\
\hline Cibicides pachyderma (Rzehak, 1886) & 0.00 & 0.44 & 0.00 & 0.29 & 0.00 & 0.00 & 0.00 & 0.00 & 0.00 & 0.00 & 0.00 & 0.00 & 0.00 & 5.09 & 0.00 \\
\hline Cibicides spp. & 0.43 & 0.00 & 0.00 & 0.58 & 0.00 & 0.22 & 0.43 & 0.00 & 0.26 & 0.12 & 2.84 & 0.00 & 1.01 & 0.02 & 2.94 \\
\hline $\begin{array}{l}\text { Cibicides wuellerstorfi (Schwager, } \\
\text { 1866) }\end{array}$ & 0.00 & 0.00 & 0.00 & 2.02 & 4.66 & 1.12 & 1.57 & 4.07 & 0.65 & 0.00 & 0.00 & 0.00 & 0.20 & 0.00 & 0.07 \\
\hline Cibicidoides spp. & 1.29 & 0.22 & 0.15 & 3.46 & 5.44 & 9.17 & 5.73 & 7.11 & 8.46 & 2.41 & 2.07 & 1.85 & 0.63 & 0.00 & 3.13 \\
\hline Cyclammina cancellata Brady, 1879 & 0.00 & 0.00 & 0.00 & 1.44 & 2.72 & 0.56 & 0.43 & 1.83 & 0.13 & 0.00 & 0.00 & 0.00 & 0.02 & 0.00 & 0.01 \\
\hline Discammina compressa (Goës, 1882) & 0.00 & 0.00 & 0.04 & 2.88 & 0.78 & 0.78 & 1.43 & 3.05 & 0.13 & 0.00 & 0.00 & 0.00 & 0.03 & 0.00 & 0.01 \\
\hline Eggerella bradyi (Cushman, 1911) & 0.00 & 0.00 & 0.00 & 2.02 & 3.89 & 0.78 & 0.00 & 1.22 & 0.39 & 0.00 & 0.00 & 0.00 & 0.01 & 0.00 & 0.01 \\
\hline Epistominella exigua (Brady 1884) & 0.00 & 0.00 & 0.00 & 7.21 & 0.00 & 0.11 & 0.72 & 1.42 & 0.00 & 0.00 & 0.00 & 0.92 & 0.02 & 0.00 & 0.01 \\
\hline $\begin{array}{l}\text { Evolvocassidulina tenuis (Phleger \& } \\
\text { Parker, 1951) }\end{array}$ & 0.00 & 0.00 & 0.00 & 0.00 & 0.00 & 0.00 & 0.00 & 0.00 & 4.88 & 0.24 & 0.13 & 0.00 & 0.00 & 0.01 & 0.00 \\
\hline Globocassidulina spp. & 0.00 & 0.00 & 0.00 & 2.88 & 8.94 & 5.37 & 5.30 & 6.50 & 4.88 & 1.08 & 0.39 & 2.00 & 0.84 & 0.00 & 10.15 \\
\hline $\begin{array}{l}\text { Globocassidulina subglobosa (Brady, } \\
\text { 1881) }\end{array}$ & 7.77 & 1.53 & 4.36 & 0.00 & 0.00 & 9.28 & 0.00 & 0.00 & 0.00 & 77.62 & 55.91 & 55.75 & 4.84 & 0.00 & 39.84 \\
\hline $\begin{array}{l}\text { Hanzawaia boueana (d'Orbigny, } \\
\text { 1846) }\end{array}$ & 0.54 & 6.99 & 0.00 & 0.00 & 0.00 & 0.00 & 0.00 & 0.00 & 0.00 & 0.72 & 0.00 & 0.00 & 0.77 & 0.43 & 0.00 \\
\hline $\begin{array}{l}\text { Haplophragmoides quadratus } \\
\text { Earland, } 1934\end{array}$ & 0.00 & 0.00 & 0.00 & 0.00 & 0.00 & 0.00 & 0.00 & 0.00 & 0.00 & 0.00 & 0.00 & 0.00 & 0.00 & 44.51 & 0.00 \\
\hline Haplophragnoides spp. & 0.00 & 0.00 & 0.00 & 2.31 & 0.00 & 1.34 & 1.72 & 4.07 & 0.26 & 0.00 & 0.00 & 0.00 & 0.00 & 0.00 & 0.05 \\
\hline $\begin{array}{l}\text { Hoeglundina elegans (d'Orbigny } \\
\text { 1826) }\end{array}$ & 0.00 & 0.00 & 0.04 & 1.44 & 1.55 & 5.48 & 6.58 & 6.30 & 0.65 & 0.00 & 0.00 & 0.00 & 0.00 & 0.00 & 0.10 \\
\hline Lagena spp. & 0.54 & 0.22 & 0.30 & 0.87 & 0.78 & 1.45 & 2.43 & 0.00 & 5.62 & 0.48 & 0.65 & 0.62 & 0.43 & 0.00 & 2.12 \\
\hline Lenticulina gibba (d'Orbigny, 1826) & 0.11 & 0.00 & 0.49 & 0.00 & 0.39 & 0.67 & 0.86 & 2.85 & 0.09 & 0.00 & 0.00 & 0.00 & 0.00 & 0.00 & 0.04 \\
\hline Lenticulina rotulata (Lamarck, 1804) & 0.00 & 0.00 & 0.00 & 0.00 & 0.00 & 0.00 & 0.00 & 0.00 & 0.00 & 0.00 & 0.00 & 3.85 & 0.00 & 0.00 & 0.00 \\
\hline $\begin{array}{l}\text { Lobatula lobatula (Walker \& Jacob, } \\
\text { 1798) }\end{array}$ & 0.76 & 3.06 & 1.20 & 0.00 & 0.00 & 0.00 & 0.00 & 0.00 & 0.00 & 0.00 & 0.00 & 0.00 & 0.00 & 0.00 & 0.00 \\
\hline $\begin{array}{l}\text { Miliolinella circularis (Bornemann, } \\
\text { 1855) }\end{array}$ & 0.97 & 1.75 & 9.17 & 0.00 & 0.00 & 0.00 & 0.00 & 0.00 & 0.00 & 0.00 & 0.00 & 0.00 & 0.00 & 0.01 & 0.00 \\
\hline $\begin{array}{l}\text { Nodulina dentaliniformis (Brady, } \\
\text { 1881) }\end{array}$ & 0.00 & 0.00 & 0.00 & 2.88 & 5.05 & 0.34 & 1.57 & 3.86 & 0.31 & 0.00 & 0.00 & 0.00 & 0.00 & 0.08 & 0.01 \\
\hline Nonionella auris (d'Orbigny, 1839) & 0.00 & 0.00 & 0.00 & 0.00 & 0.00 & 1.23 & 0.72 & 0.00 & 4.88 & 0.12 & 1.42 & 0.31 & 0.07 & 0.33 & 0.84 \\
\hline Oridorsalis umbonatus (Reuss, 1851) & 4.31 & 0.00 & 0.00 & 0.00 & 0.00 & 0.00 & 0.00 & 0.00 & 0.04 & 0.00 & 0.00 & 0.00 & 0.00 & 0.00 & 0.00 \\
\hline $\begin{array}{l}\text { Osangularia bengalensis (Schwager, } \\
\text { 1866) }\end{array}$ & 0.00 & 0.00 & 0.00 & 0.00 & 0.00 & 4.59 & 0.00 & 0.00 & 0.17 & 0.00 & 0.00 & 0.00 & 0.00 & 0.00 & 0.00 \\
\hline Pyrgo sarsi (Schlumberger, 1891) & 0.00 & 0.11 & 4.40 & 0.00 & 0.00 & 0.00 & 0.00 & 0.00 & 0.00 & 0.00 & 0.00 & 0.00 & 0.00 & 0.00 & 0.00 \\
\hline
\end{tabular}


Appendix 1 (cont.). Percentage of foraminiferal species in the studied samples ( $>3 \%$ in at least one station).

\begin{tabular}{|c|c|c|c|c|c|c|c|c|c|c|c|c|c|c|c|}
\hline Station & 1 & 2 & 3 & 4 & 5 & 6 & 7 & 8 & 9 & 10 & 11 & 12 & 13 & 14 & 15 \\
\hline $\begin{array}{l}\text { Planulina ariminensis d'Orbigny, } \\
1826\end{array}$ & 1.40 & 4.37 & 1.50 & 30.58 & 0.00 & 0.00 & 0.00 & 0.00 & 0.00 & 0.00 & 0.00 & 0.00 & 0.00 & 0.00 & 0.00 \\
\hline Pseudogaudryina spp. & 0.00 & 0.00 & 4.51 & 0.00 & 0.00 & 0.00 & 0.00 & 0.00 & 0.00 & 0.00 & 0.00 & 0.00 & 0.02 & 0.00 & 0.00 \\
\hline Pullenia quinqueloba (Reuss, 1851) & 0.11 & 3.93 & 2.56 & 0.00 & 0.00 & 0.00 & 0.00 & 0.00 & 0.00 & 0.00 & 0.00 & 0.00 & 0.00 & 0.00 & 0.00 \\
\hline Pyrgo sarsi (Schlumberger, 1891) & 0.00 & 0.11 & 4.40 & 0.00 & 0.00 & 0.00 & 0.00 & 0.00 & 0.00 & 0.00 & 0.00 & 0.00 & 0.00 & 0.00 & 0.00 \\
\hline Pyrgo spp. & 0.11 & 3.49 & 3.23 & 0.00 & 1.55 & 0.34 & 0.00 & 0.20 & 0.26 & 0.36 & 0.13 & 0.00 & 0.01 & 0.00 & 0.00 \\
\hline Rhabdammina spp. & 0.00 & 0.00 & 0.01 & 2.50 & 9.72 & 2.27 & 2.77 & 4.34 & 0.20 & 0.00 & 0.00 & 0.00 & 0.09 & 0.06 & 0.05 \\
\hline Rhizammina spp. & 0.00 & 0.00 & 0.00 & 0.58 & 1.30 & 0.52 & 3.20 & 2.91 & 0.19 & 0.00 & 0.00 & 0.00 & 0.03 & 0.03 & 0.02 \\
\hline Rosalina spp. & 18.23 & 5.68 & 1.95 & 0.00 & 2.72 & 0.22 & 0.29 & 0.00 & 0.00 & 1.32 & 6.84 & 7.70 & 0.14 & 1.00 & 11.74 \\
\hline $\begin{array}{l}\text { Sigmoilopsis schlumbergeri } \\
\text { (Silvestri, 1904) }\end{array}$ & 0.00 & 0.00 & 0.19 & 2.60 & 3.11 & 1.01 & 3.29 & 2.85 & 0.44 & 0.00 & 0.00 & 0.00 & 0.01 & 0.09 & 0.04 \\
\hline $\begin{array}{l}\text { Siphotextularia concava (Karrer, } \\
1868 \text { ) }\end{array}$ & 0.00 & 0.00 & 4.51 & 0.00 & 0.00 & 0.00 & 0.00 & 0.00 & 0.00 & 0.00 & 0.00 & 0.00 & 0.00 & 0.00 & 0.00 \\
\hline $\begin{array}{l}\text { Textularia pseudogramen Chapman } \\
\text { \& Parr, } 1937\end{array}$ & 0.00 & 2.62 & 4.47 & 0.00 & 0.00 & 0.00 & 0.00 & 0.00 & 0.00 & 0.00 & 0.00 & 0.00 & 0.38 & 0.00 & 0.00 \\
\hline Textularia spp. & 0.22 & 4.37 & 2.14 & 0.87 & 0.78 & 0.00 & 0.14 & 0.61 & 0.00 & 0.00 & 0.00 & 0.00 & 0.06 & 0.01 & 0.01 \\
\hline Trifarina bradyi Cushman, 1923 & 0.00 & 0.44 & 0.00 & 0.58 & 0.78 & 3.02 & 0.14 & 0.20 & 4.88 & 0.00 & 0.00 & 0.00 & 0.19 & 1.35 & 0.01 \\
\hline $\begin{array}{l}\text { Triloculina trigonula (Lamarck, } \\
\text { 1804) }\end{array}$ & 0.00 & 0.00 & 2.86 & 0.00 & 0.00 & 0.00 & 0.00 & 0.00 & 0.00 & 0.00 & 0.00 & 0.00 & 0.00 & 0.00 & 0.00 \\
\hline $\begin{array}{l}\text { Trochammina globigeriniformis } \\
\text { (Parker \& Jones, 1865) }\end{array}$ & 0.76 & 0.00 & 0.00 & 0.29 & 0.39 & 0.45 & 0.00 & 0.00 & 0.00 & 0.00 & 0.00 & 0.00 & 20.40 & 0.00 & 0.00 \\
\hline $\begin{array}{l}\text { Uvigerina auberiana d' Orbigny } \\
1839\end{array}$ & 0.00 & 2.62 & 6.01 & 0.87 & 0.39 & 2.24 & 0.00 & 0.00 & 0.22 & 0.00 & 0.00 & 0.00 & 0.60 & 0.08 & 0.00 \\
\hline $\begin{array}{l}\text { Uvigerina mediterranea Hofker, } \\
1932\end{array}$ & 7.34 & 0.00 & 0.00 & 0.00 & 0.00 & 0.89 & 0.29 & 0.00 & 0.04 & 0.60 & 11.49 & 4.77 & 1.73 & 1.00 & 0.42 \\
\hline Uvigerina peregrina Cushman, 1923 & 9.06 & 22.05 & 4.21 & 11.54 & 21.37 & 2.68 & 17.46 & 25.61 & 1.26 & 0.72 & 1.42 & 2.00 & 5.53 & 0.01 & 0.26 \\
\hline Uvigerina spp. & 10.79 & 0.00 & 1.50 & 2.60 & 0.00 & 1.90 & 1.43 & 0.00 & 5.58 & 1.08 & 2.71 & 4.62 & 1.42 & 2.33 & 3.36 \\
\hline
\end{tabular}


Plate 1. 1 - Bolivina fragilis Phleger \& Parker, 1951; 2 - Cassidulina carinata Silvestri, 1839; 3 - Cassidulina curvata Phleger \& Parker, 1951; 4 - Globocassidulina subglobosa (Brady, 1881); 5 - Hoeglundina elegans (d'Orbigny, 1878); 6 - Nodulina dentaliniformis (Brady, 1881); 7 - Uvigerina auberiana d'Orbigny, $1839 ; 8$ Uvigerina auberiana d'Orbigny, 1839; 9 - Uvigerina peregrina Cushman, 1923.

\section{Plate 1}

1

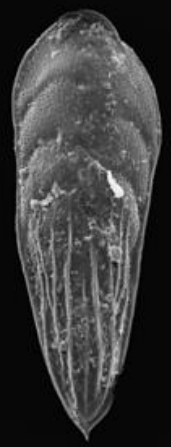

$-\quad 30 \mu \mathrm{m}$

4

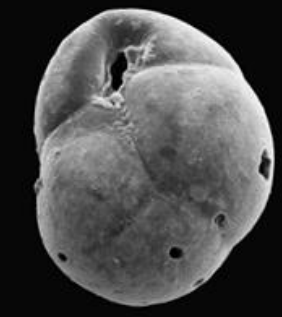

$-\quad 20 \mu \mathrm{m}$

7

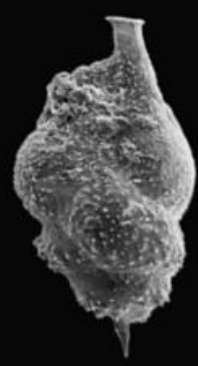

$-20 \mu \mathrm{m}$
2

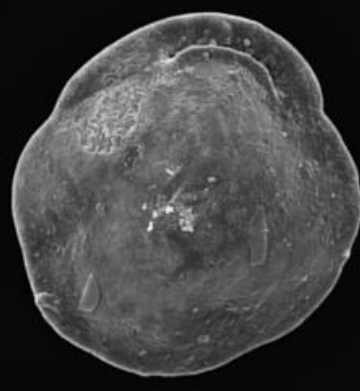

$-20 \mu \mathrm{m}$

5

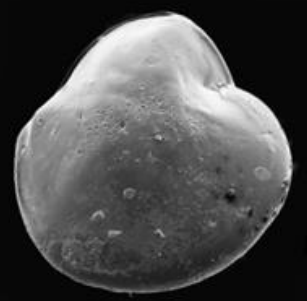

- $\quad 100 \mu \mathrm{m}$

8

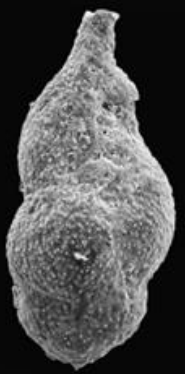

$-20 \mu \mathrm{m}$
3

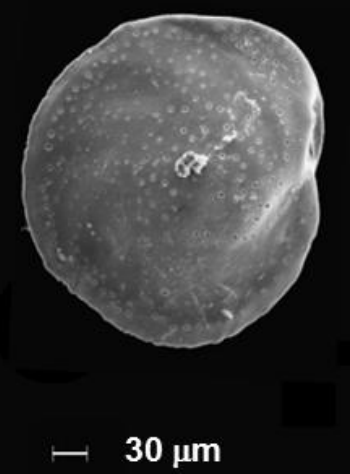

6

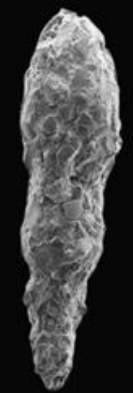

$\longrightarrow \quad 100 \mu \mathrm{m}$

9

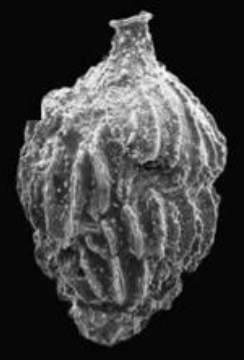

$100 \mu \mathrm{m}$ 